\title{
Tubulideres seminoli gen. et sp. nov. and Zelinkaderes brightae sp. nov. (Kinorhyncha, Cyclorhagida) from Florida
}

\author{
Martin V. Sørensen · Iben Heiner · Ole Ziemer • \\ Birger Neuhaus
}

Received: 27 November 2006 / Revised: 15 March 2007 / Accepted: 10 May 2007 / Published online: 20 June 2007

(C) Springer-Verlag and AWI 2007

\begin{abstract}
One new kinorhynch genus and species and one new species from the genus Zelinkaderes are described from sandy sediment off Fort Pierce, Florida. The new genus and species, Tubulideres seminoli gen. et sp. nov. is characterized by the presence of the first trunk segment consisting of a closed ring, the second segment of a bent tergal plate with a midventral articulation and the following nine segments consisting of a tergal and two sternal plates. Cuspidate spines are not present, but flexible tubules are located on several segments, and in particular concentrated on the ventral side of the second segment. Middorsal spines are present on all trunk segments and are alternatingly offset to a position slightly lateral to the middorsal line. Zelinkaderes brightae nov. sp. is characterized by its spine formula in having middorsal spines on trunk segments 4,6 and 8-11, lateroventral acicular spines on segment 2, lateral accessory cuspidate spines on segments 2 and 8, ventrolateral cuspidate spines on segments 4-6 and 9, lateroventral acicular spines present on segments 8 and 9 , and midterminal,
\end{abstract}

Communicated by Peter Funch.

M. V. Sørensen ( $\square)$

Ancient DNA and Evolution Group,

Niels Bohr Institute and Biological Institute,

University of Copenhagen, Juliane Maries Vej 30,

2100 Copenhagen, Denmark

e-mail: mvsorensen@bi.ku.dk

I. Heiner $\cdot$ O. Ziemer

Invertebrate Department, Zoological Museum,

University of Copenhagen, Copenhagen, Denmark

B. Neuhaus

Museum für Naturkunde der Humboldt-Universität zu Berlin,

Berlin, Germany lateral terminal and lateral terminal accessory spines on segment 11 . The spine formula of $Z$. brightae nov. sp. places it in a position in between $Z$. submersus and a clade consisting of $Z$. klepali and $Z$. floridensis. The new findings on $Z$. brightae nov. sp. have led us to propose an emended diagnosis for the genus.

Keywords Kinorhyncha $\cdot$ Tubulideres seminoli . Zelinkaderes brightae $\cdot$ New genus $\cdot$ Marine meiofauna

\section{Introduction}

By the end of 2006, the phylum Kinorhyncha comprises about 150 species, based on descriptions of adult stages (Neuhaus and Higgins 2002; Sørensen et al. 2005; Sørensen 2006). The species are distributed on 10 families and 16 genera. The phylum is divided into two orders, Homalorhagida and Cyclorhagida, of which the latter is the largest both concerning number of genera and species. It also displays the broadest morphological disparity. Cyclorhagida contains a total of 10 genera, and one of them, Echinoderes, nests with its more than 50 species more than one-third of the total number of valid kinorhynch species. None of the remaining cyclorhagid genera contains more than 10 species. The most recent summary of the kinorhynch biodiversity was given by Adrianov and Malakhov (1999), but newer contributions should be consulted as well to obtain a complete overview (Pardos et al. 1998; Sørensen et al. 2000, 2005; Adrianov et al. 2002a, b; Lemburg 2002; Neuhaus and Higgins 2002; Martorelli and Higgins 2004; Neuhaus 2004; Sørensen 2006; Neuhaus and Blasche 2006). Of the 16 known kinorhynch genera, 5 have been described within the last 20 years, and all of them have been assigned to the Cyclorhagida (Higgins 1990; Higgins 
and Shirayama 1990; Nebelsick 1990; Adrianov and Malakhov 1999; Neuhaus and Blasche 2006). Nebelsick (1990) described the genus Antygomonas from subtidal mediumgrained sand in the Adriatic Sea, and within the same year two other new kinorhynch genera were described. Higgins (1990) established the new genus Zelinkaderes, partly based on a newly discovered species, Zelinkaderes floridensis Higgins (1990), and partly based on a species, Z. submersus (Gerlach 1969) that previously was assigned to Cateria (see Gerlach 1969). Higgins and Shirayama (1990) described the new species and genus Dracoderes abei from subtidal sandy mud off the coast of Japan. Nine years later, Adrianov re-evaluated the generic position of Echinoderes asiaticus Adrianov (1989) and revealed several unique characters, which prompted the establishment of the genus Cephalorhyncha, to which the species was reassigned (Adrianov and Malakhov 1999). Most recently, Neuhaus and Blasche (2006) described Fissuroderes, including five species from New Zealand and Costa Rica, and assigned the new genus to the family Echinoderidae together with Echinoderes and Cephalorhyncha.

The ongoing discovery of new taxa and information obtained by exploration of new habitats such as the deep sea (Neuhaus 2004; Neuhaus and Blasche 2006), indicate that we still have not revealed the full morphological and taxonomical variety of the kinorhynchs. At present our knowledge on the kinorhynch phylogeny is still extremely limited (Neuhaus and Higgins 2002), hence discoveries of new taxa and further information about the morphological disparity are extremely valuable factors to obtain an improved understanding of the kinorhynch relationships.

In this paper, we report the finding of a new cyclorhagid genus and species, Tubulideres seminoli gen. et sp. nov., and one new species, Zelinkaderes brightae sp. nov., from sandy sediments at $15 \mathrm{~m}$ depth off Fort Pierce, Florida. The new entities are described and the kinorhynch relationships are discussed in the light of this new finding.

\section{Materials and methods}

The material was taken with a meiofauna dredge from the research vessel R/V Sunburst, belonging to the Smithsonian Marine Station at Fort Pierce. It was collected from sandy sediments (Dentalium sand) on 22 July 2003 at $15.1 \mathrm{~m}$ in the Atlantic Ocean, on the locality Inlet Sand Spoil off Fort Pierce, Florida $\left(27^{\circ} 29.56^{\prime} \mathrm{N}, 080^{\circ} 12.23^{\prime} \mathrm{W}\right)$. The water temperature was $15.3^{\circ} \mathrm{C}$ and the salinity was $35 \%$ o. Additional material was collected in April 2004 and May 2006 on the same, and nearby localities (5 mile station $27^{\circ} 29.96^{\prime} \mathrm{N}, 080^{\circ} 12.67^{\prime} \mathrm{W} ; 6$ mile station $27^{\circ} 29.11^{\prime} \mathrm{N}$, $080^{\circ} 11.02^{\prime} \mathrm{W}$ ). The specimens in the samples were either freshwater-shocked or anesthetized with a 35\% solution of magnesium sulphate and decanted through a net with $63 \mu \mathrm{m}$ mesh width.

Animals were sorted under an Olympus SZX12 dissecting microscope. Specimens for light microscopy were dehydrated through a graded series of glycerine and mounted in Fluoromount $G^{\circledR}$. Fluoromount $G^{\circledR}$ is a nonfluorescent mounting medium that usually is used to mount specimens for fluorescence or confocal microscopy. However, it has proven to be useful for kinorhynchs as well, since it is viscous like other mounting media, such as Faure's and Hoyer's medium, but lacks the chloral hydrate, that often bleaches the mounted specimens so much that they may disappear after a certain time. The mounted specimens were examined and photographed using Nomarski differential interference contrast with an Olympus BX51 microscope equipped with an Olympus C-5060SIS digital camera. Photos for the light microscope plates were made from Z-projections of 2-3 photos taken in slightly different focus planes. The projections were made with $\mathrm{SIS}$ cell ${ }^{\wedge} \mathrm{D}$ imaging software. Habitus drawings were made with a camera lucida.

Specimens for SEM were dehydrated through a graded series of ethanol, transferred to acetone and critical point dried. The dried specimens were mounted on aluminium stubs, sputter coated and examined with a JEOL JSM6335F field emission scanning electron microscope.

From the Natural History Museum in Vienna and Dr. Monika Bright's personal collection, specimens of Antygomonas oreas were borrowed for comparison with Tubulideres seminoli gen. et sp. nov. Specimens of Zelinkaderes floridensis and $Z$. submersus were borrowed from the National Museum of Natural History, Smithsonian Institution, Washington DC.

In the following descriptions we have adopted the terminology used by Brown (1989) for the mouth cone appendages, whereas we follow the system proposed by BauerNebelsick $(1995,1996)$ in the naming of rings in the mouth cone and introvert. For the naming of main body regions and segments we follow Neuhaus and Higgins (2002) and Neuhaus and Blasche (2006), hence dividing the adult kinorhynch specimen into a head, a neck, and a trunk consisting of segments $1-11$. We prefer to use this numbering in the present and in future contributions, and encourage other authors to adopt this system as well.

\section{Descriptions}

Order Cyclorhagida Zelinka, 1896

Suborder Cyclorhagae Zelinka, 1896

Genus Tubulideres gen. nov. 
Diagnosis Neck consisting of 16 placids; placids fused basally with first trunk segment. First trunk segment circular in cross-section, consisting of one complete ring; anterior margin straight, posterior margin with wedge-shaped midventral extension. Second segment consisting of a tergal plate with midventral articulation. Trunk segments 3-10 more triangular in cross-section, consisting of one tergal plate and two sternal plates; posterior margins of segments deeply fringed with distinct ventromedial and lateroventral notches. Middorsal spines present on trunk segments 1 through 11, located near posterior margins of segments, alternatingly offset from midline; posterior margins with small, paired notches at base of middorsal spine. Segment 2 with two pairs of thick, ventromedial tubules and one pair of thick, lateroventral tubules located close to pair of thin, flexible spines; group with ventromedial tubules and lateroventral tubule/spine separated by wedge-shaped, fringed extensions from posterior margin of segment. Segments 5 and 7 with lateroventral tubules, and segments 4 through 9 with lateroventral acicular spines. Segment 10 in males with middorsal and subdorsal spines; spines are flexible, appearing segmented or moniliform in distal ends; females with middorsal and subdorsal acicular spines. Terminal trunk segment with middorsal spine, midterminal spine, lateral terminal spines and lateral terminal associated spines lateral terminal spines and lateral terminal accessory spines of same lengths.

Type species Tubulideres seminoli gen. et sp. nov.

Etymology The prefix "Tubuli-" is derived from the Latin "tubulus" = tube, and refers to the numerous ventral tubules on trunk segment 2. The suffix "-deres" is from Greek, meaning "neck", and is used in the naming of most cyclorhagid genera.

Tubulideres seminoli gen. et sp. nov. (Figs. 1, 2, 3, 4, 5, 6; Tables 1, 2, 3)
Fig. 1 Tubulideres seminoli gen. et sp. nov. a Male dorsal view. b Male ventral view. c Segment 11 and terminal spines, drawn in same scale as $\mathbf{a}$ and $\mathbf{b}$. d Female, left part of trunk segments 10-11, dorsal view. e Female, left part of trunk segments 10-11 ventral view

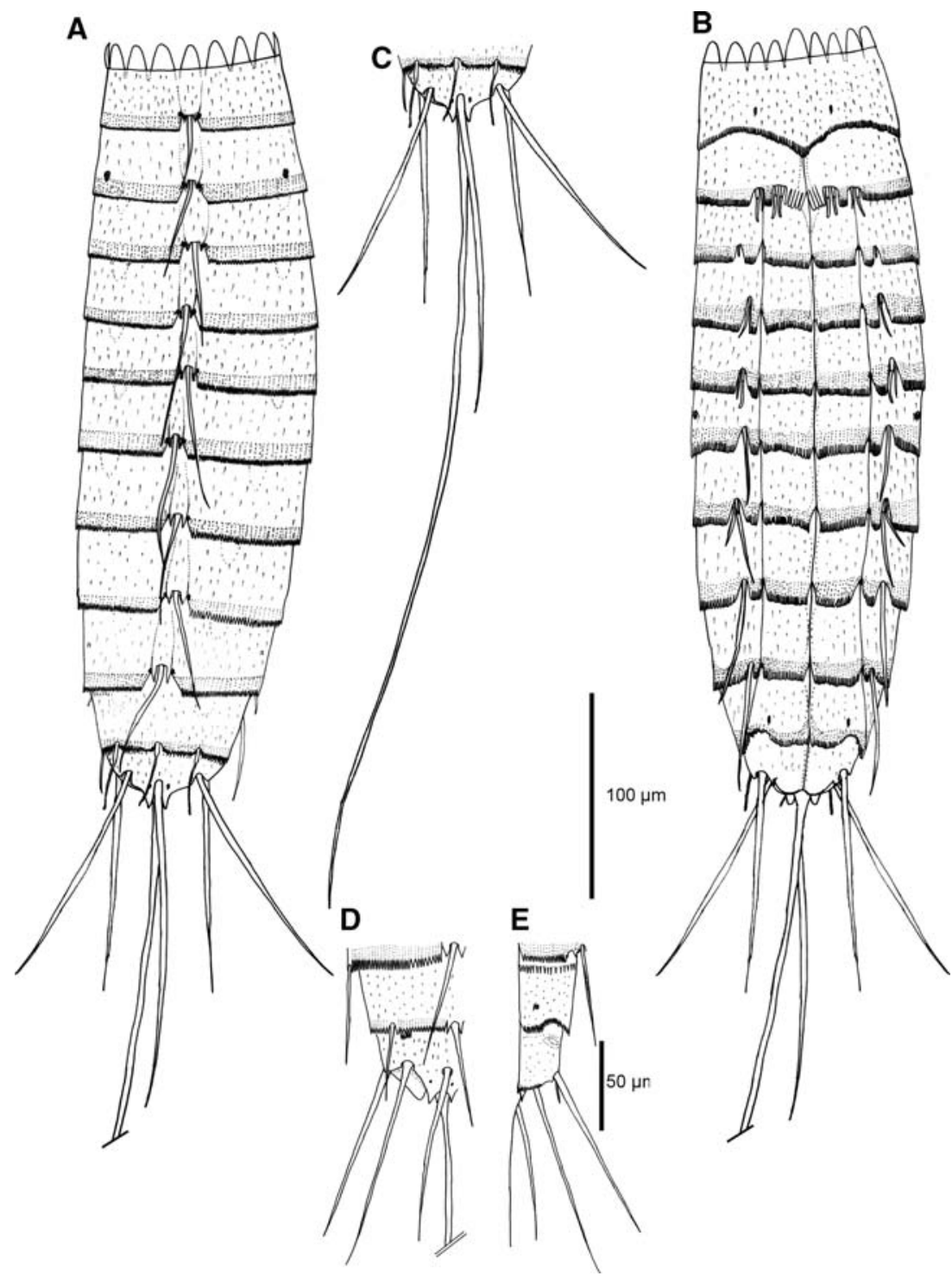


Fig. 2 Light microscope photos of Tubulideres seminoli gen. et sp. nov. Holotypic male: a ventral view. b Trunk segments 1-8 dorsal view. c Trunk segments 1-8 ventral view. d Trunk segments 7-11 dorsal view. e Trunk segments 7-11 ventral view.

f Introvert and trunk segments 1-2 dorsal view. $\mathrm{g}$ Trunk segments 10-11 dorsal view. Allotypic female: h Trunk segments 10-11 ventral view. go Gonopore; la lateral articulation; $l v$ lateroventral tubules; $m v p$ midventral placid; $s d s$ subdorsal spine (male type); $v m$ ventromedial tubules
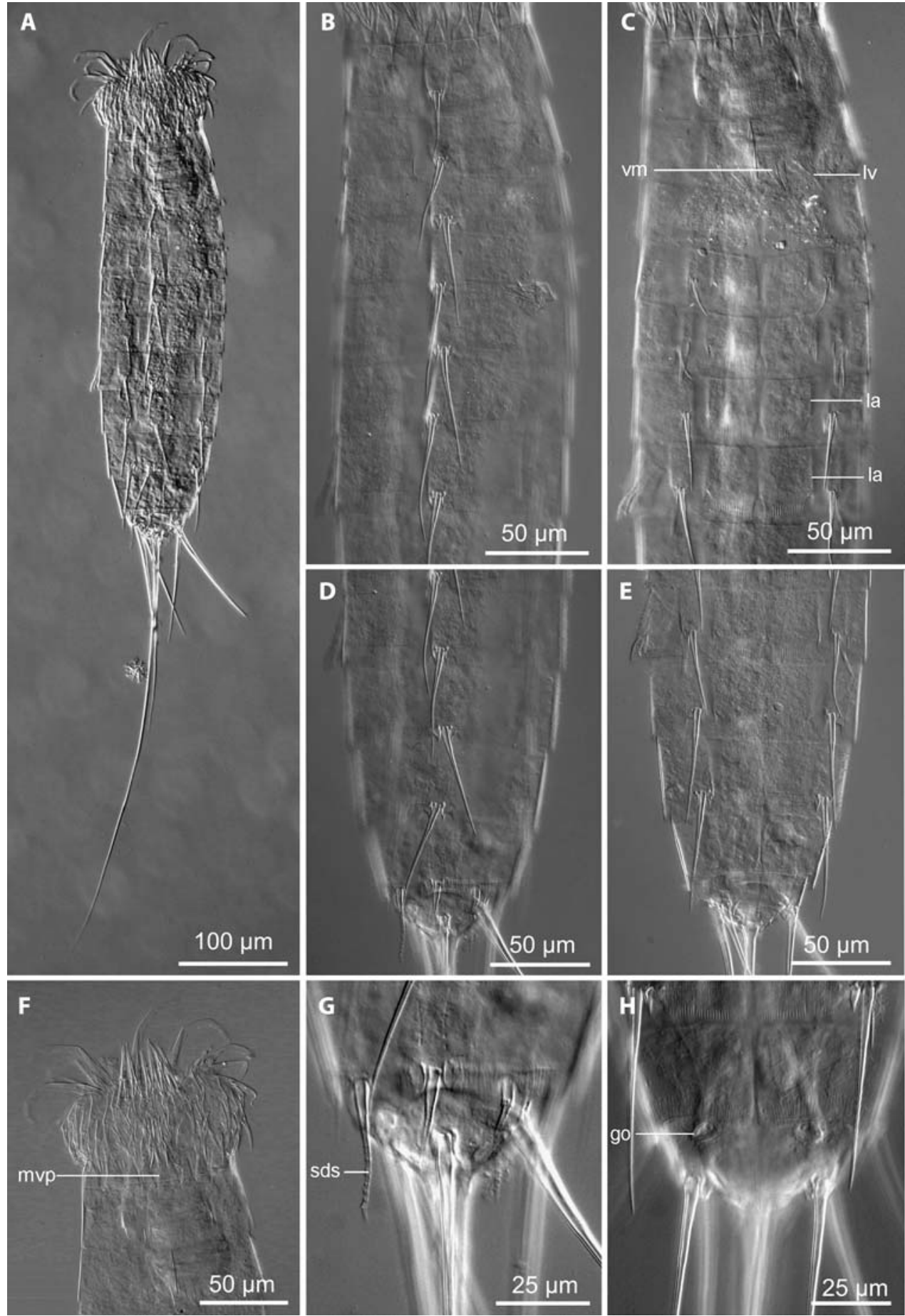

Diagnosis Same as genus diagnosis.

Etymology The species name "seminoli" refers to the Floridian Seminole Indians.

Material examined All type material was obtained from a sample taken on 22 July 2003 in the Atlantic Ocean, at Inlet Sand Spoil off Fort Pierce, Florida. Position $27^{\circ} 29.559^{\prime} \mathrm{N}$, $080^{\circ} 12.233^{\prime} \mathrm{W}$. Holotype adult male, mounted in Fluoro- mount $\mathrm{G}^{\circledR}$ (ZMUC KIN-172). Allotype adult female, mounted in Fluoromount $\mathrm{G}^{\circledR}$ (ZMUC KIN-173). Paratypes five adult females and five adult males, mounted in Fluoromount $\mathrm{G}^{\circledR}$ (ZMUC KIN-174 to KIN-183). Additional material was collected at the same and nearby localities (5 and 6 mile station) in April 2004 and May 2006. All types are stored at the Zoological Museum, University of Copenhagen. 


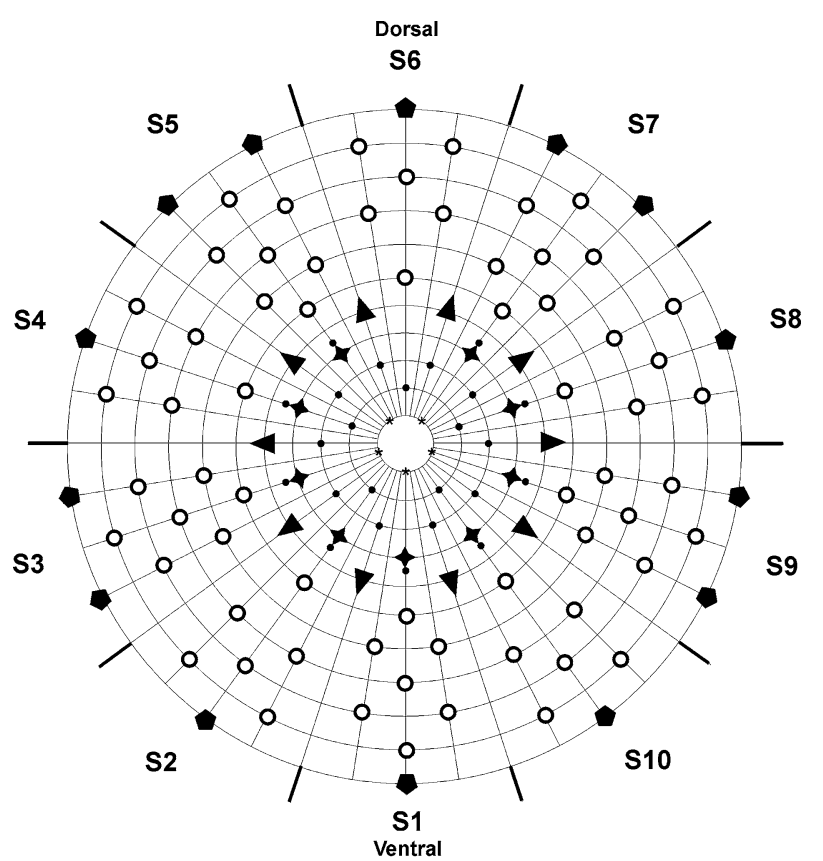

Tubulideres seminoli nov. gen. et nov spec.
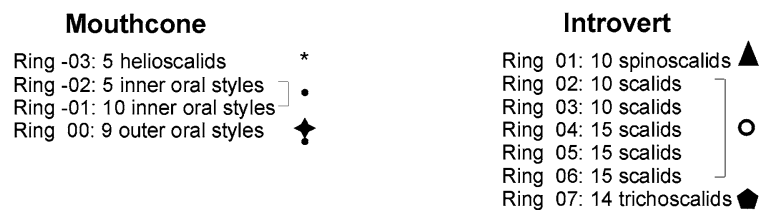

Fig. 3 Diagram of mouth cone and introvert showing distribution of oral styles and scalids in Tubulideres seminoli gen. et sp. nov

Additional material is stored in the Museum für Naturkunde der Humboldt-Universität zu Berlin and in MVS' personal collection.

Description The adult specimens possess a head, a neck and eleven trunk segments (Figs. 1a, b, 2a, 4a, b ). All measurements and dimensions are given in Tables 1, 2. A summary of spine, tubule and sensory spot locations is given in Table 3.

The head consists of a mouth cone with one ring of helioscalids and three rings of oral styles and an introvert with seven rings of scalids (Figs. 2f, 3, 4c-e). In the following description the ring with the outer oral styles will define ring 0 , hence rings in the mouth cone will be numbered $-01,-02$, and -03 for the innermost ring, whereas rings in the introvert will be referred to as ring 01 (spinoscalids) to ring 07 (trichoscalids). The innermost ring (ring -03) carries five helioscalids, followed by two rings with inner oral styles (five and ten, respectively). The oral styles have a torsion to the right, but with differing windings. All inner oral styles have a terminal pore. The fourth ring (ring 0) has nine, much longer outer oral styles with fringed bases (Fig. 4d-e). All outer styles consist of two segments, and a claw-like structure on the tip (Fig. 4d). A small pore is located right below the claw. The first scalid ring (ring 01) consists of ten spinoscalids. The spinoscalids appear stout and divide the rest of the introvert into ten sections (Fig. 3). The scalids of the rings 02-06 are all pointed and decrease in size gradually. The number of scalids is indicated in Fig. 3. The seventh and most posterior ring consists of 14 trichoscalids in similar sizes and appearance (Figs. 3, 4e). The position of scalids alternates in each ring, so that two scalids in two following rows never sit in equivocal positions. Only the midventral radius arm has four ordinary scalids in one row (rings 02, 04, 06 and 07). In summary, the distribution of scalids is: $5,5,10,9 / 10,10,10,15,15,15$, 14.

The arrangement of scalids in the introvert can be described section-wise instead of ring-wise. The midventral section will be section 1 , followed in clockwise direction by section 2 , and then section 3 , etc. (Fig. 3). All sections (except the middorsal section 6) would contain one oral style, and section 1 would furthermore have seven scalids and one trichoscalid; sections 2, 4, 8, 10: six scalids and one trichoscalid; sections 3, 5, 7, 9: seven scalids and two trichoscalids, and the middorsal section 6: six scalids and one trichoscalid.

The neck consists of 16 placids, measuring 13-14 $\mu \mathrm{m}$ in length. The midventral placid is wider than the remaining placids, measuring $11 \mu \mathrm{m}$ at the base (Fig. 2f); the remaining placids measure $6 \mu \mathrm{m}$ at their bases. The placids are fused with the first trunk segment and the margin between the neck and first trunk segment is visible as an indistinct line only. The basal parts of the lateral placid margins are visible as indistinct lines on the anterior part of segment 1 .

Segment 1 consists of one complete ring. The posterior margin is fringed with paired sinuate incisions on the ventral side. Midventrally the fringes form a wedge-shaped extension (Figs. 1b, 4b, 5c). A middorsal spine with a pair of paradorsal sensory spots is present on the posterior margin of the segment. The base of the middorsal spine is flanked by a pair of notches (Figs. 5a, 6d). The middorsal spines on this and the following segments are not located exactly on the middorsal line, but are alternatingly slightly offset to the midline (Figs. 1a, 2b, d, 5a, b). This trait is most distinct in live and moving specimens. A pair of ventromedial sensory spots is present (Figs. 1b, 5c). The sensory spots are droplet-shaped and consist of numerous short papillae and 1 (2?) central pore. Cuticular hairs are short and thin, and densely scattered over the surface of the entire segment.

Segment 2 consists of one tergal plate that bends and fuses midventrally (Figs. 1b, 2c). The trunk cuticle appears to be of medium thickness, but still relatively flexible. A secondary fringe is located anteriorly on the segment. The posterior margin of the dorsal side has a pectinate fringe, similar to the one on segment 1 , and a middorsal spine, 
Fig. 4 Scanning electron micrographs of Tubulideres seminoli gen. et sp. nov. a Male dorsal view. b Male ventral view. c Mouth cone and oral styles frontal view. d. Mouth cone and oral styles laterofrontal view. e Introvert lateral view of sectors 5 and $6 . h s$ helioscalid; $j$ joint; $m c$ mouth cone; os outer oral style; $s p$ spinoscalid; $t s$ trichoscalid
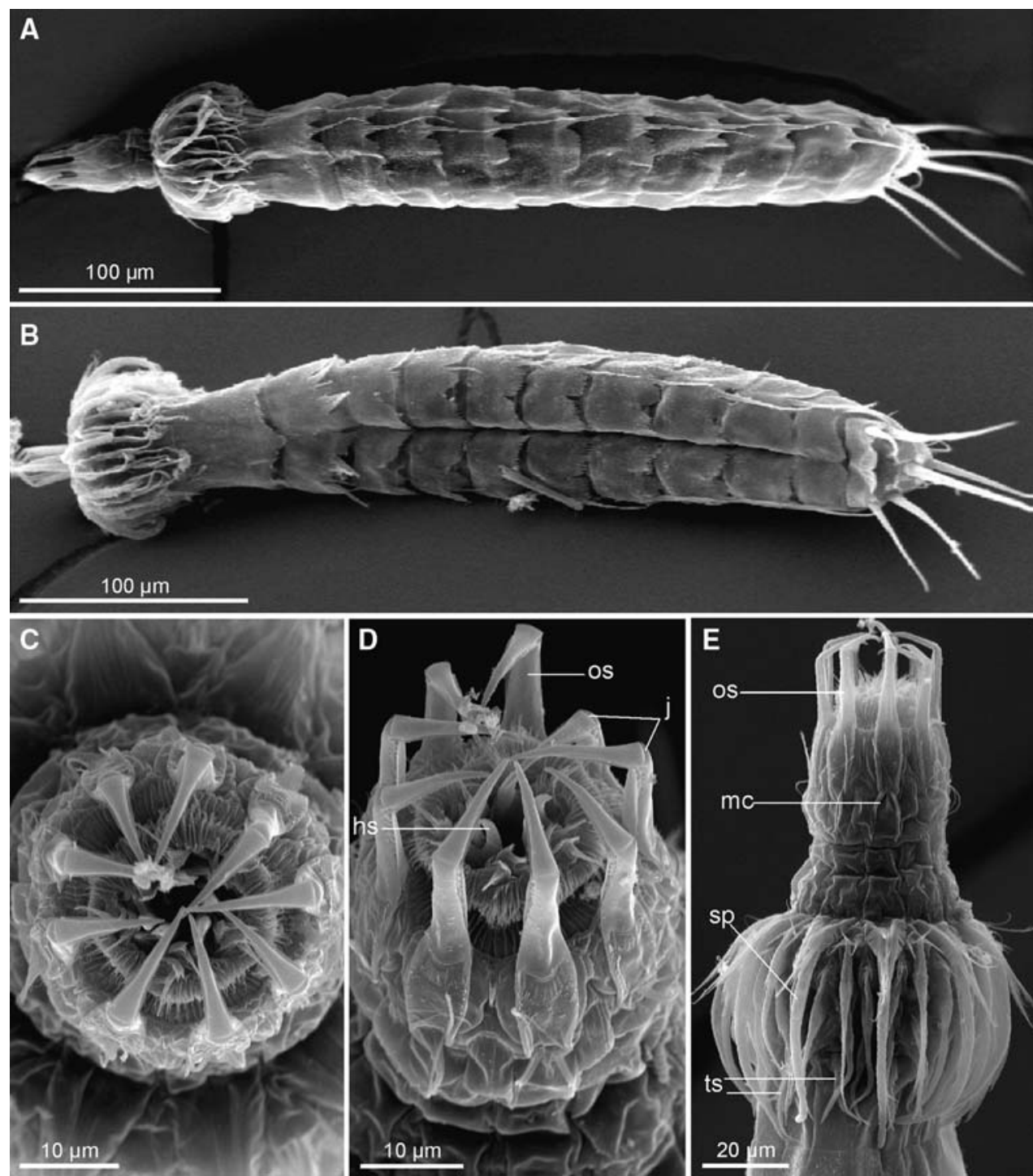

flanked by paired paradorsal sensory spots and basal notches. A pair of large, rounded sensory spots, consisting of numerous short papillae and 1 central pore, is present in a laterodorsal position (Figs. 1a, 6b). The posterior margin of the lateral and ventral sides is more conspicuously fringed and characterized by the presence of deep lateroventral and ventromedial incisions. The two incisions on each plate are separated by a narrow fringed, truncated flap, whereas a broader flap is located close to the midventral line. The flaps around the midventral line carry prominent combs or fringes that are distinctively longest at the midventral line. Two pairs of ventromedial tubules and one pair of lateroventral tubules next to a pair of acicular spines are located in their respective incisions near the posterior margin of the segment (Figs. 1b, 2c, 5c, 6a). The shape and size of the tubules may vary, but in most species they are thick and prominent. The most lateral tubule appears to be slightly larger than the two midventral ones (Fig. 6a). The thick tubules consist of a broad prominent basis without hairs and a slightly thinner distal part which is densely covered with cuticular hairs. The lateroventral acicular spines resemble the tubules, but are much thinner and shorter, with more inconspicuous hair patterns and differentiation into a basis and a distal part, and without the distal pore that otherwise characterize the tubules. Short cuticular hairs are densely scattered over the segment. The hairs on the tergal plate are slightly longer than those on the sternal plates.

Segment 3 and the following segments consist of one tergal plate and probably two sternal plates. The lateral tergal-sternal junctions are very indistinct, whereas the midventral junction is conspicuous. The posterior margin of the dorsal side has a fringe and a middorsal spine, flanked by a pair of paradorsal sensory spots and basal notches. Sensory spots are not present on the tergal plate. The posterior margins of the lateral and ventral side have two pairs of deep incisions in the same position as those on the previous 
Fig. 5 Scanning electron micrographs of Tubulideres seminoli gen. et sp. nov. a Male, trunk segments 1-5 dorsal view. b Male, trunk segments 7-11 dorsal view. c Male, trunk segments 1-6 ventral view. d Male, trunk segments $7-11$ ventral view. e. Female, trunk segments 10-11 lateral view. f Male, trunk segments 10-11 lateral view. g Female, trunk segments 9-11 ventral view. $\mathbf{h}$ Female, terminal trunk segment ventral view. go gonopore; ld laterodorsal spine; ltas lateral terminal accessory spine; lts lateral terminal spine; $l v$ lateroventral tubule; $m d$ middorsal spine; mss modified sensory spot; mve midventral extension; $s d$ subdorsal spines in male (m) and female (f); ss sensory spot; $v m$ ventromedial tubules. Digits after spines/tubules refer to segment number
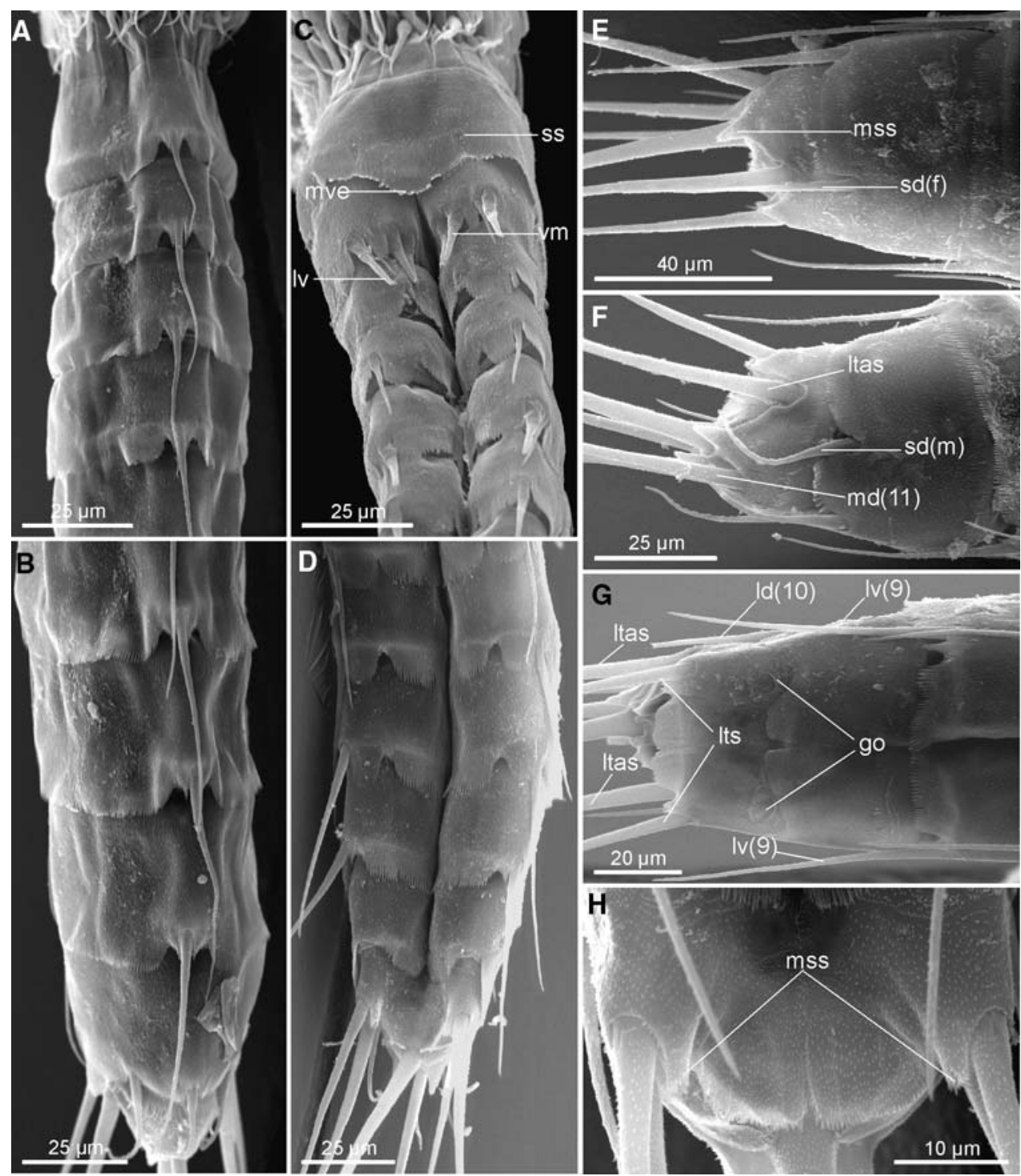

segment, but tubules are not present (Fig. 5c). An area with densely set, short papillae in the ventromedial incision may be a modified sensory spot (Fig. 6e). Cuticular hairs cover the segment completely, except in an elongate midlateral area that is totally devoid of hairs. On this and the following segments the hairs gradually become shorter and more scale-like.

Segment 4 possesses a prominent secondary fringe at the anterior margin of the segment. The posterior margin of the dorsal side shows a fringe and a middorsal spine, flanked by a pair of paradorsal sensory spots and basal notches. Otherwise, sensory spots are not present on the tergal plate. The posterior margins of the lateral and ventral side have two pairs of deep incisions in the same position as those on the previous segment. A short, flexible lateroventral acicular spine is present in the lateroventral incision (Figs. 1b, $2 \mathrm{c}, 5 \mathrm{c})$. The spine has a smooth base and a flexible distal part with short hairs, hence resembling the short lateroven- tral spine on segment 2. A sensory spot is located in the ventromedial incision. Cuticular hairs are short, scale-like and evenly distributed over the segment, except in the less hirsute midlateral areas.

Segment 5 shows a prominent secondary fringe at the anterior margin of the segment. A fringe and a middorsal spine, flanked by a pair of paradorsal sensory spots and basal notches, are located at the posterior margin of the dorsal side. Otherwise, sensory spots are not present on the tergal plate. The posterior margins of the lateral and ventral side have two pairs of deep incisions in the same position as those on the previous segment. A short, flexible acicular spine and a slightly larger tubule are present in each of the lateroventral incisions (Figs. 1b, 2c, 5c). The spine is located closest to the midventral line. A sensory spot is located in the ventromedial incision. Cuticular hairs are short and scale-like, evenly distributed over the segment, except in the less hirsute midlateral areas. 
Fig. 6 Scanning electron micrographs of details in Tubulideres seminoli gen. et sp. nov. a Tubules on posterior margin of sternal plate of trunk segment 2 . b Laterodorsal sensory spot on trunk segment 2. c Cuticular pore on trunk segment 9. d Paradorsal sensory spots close to middorsal spine on trunk segment 6. e Ventromedial sensory spot on trunk segment 3. f Paradorsal sensory spot on terminal trunk segment. $l v$ Lateroventral spine/tubule; po pore; ss sensory spot; $v m$ ventromedial tubules. Digits after spines/tubules refer to segment number
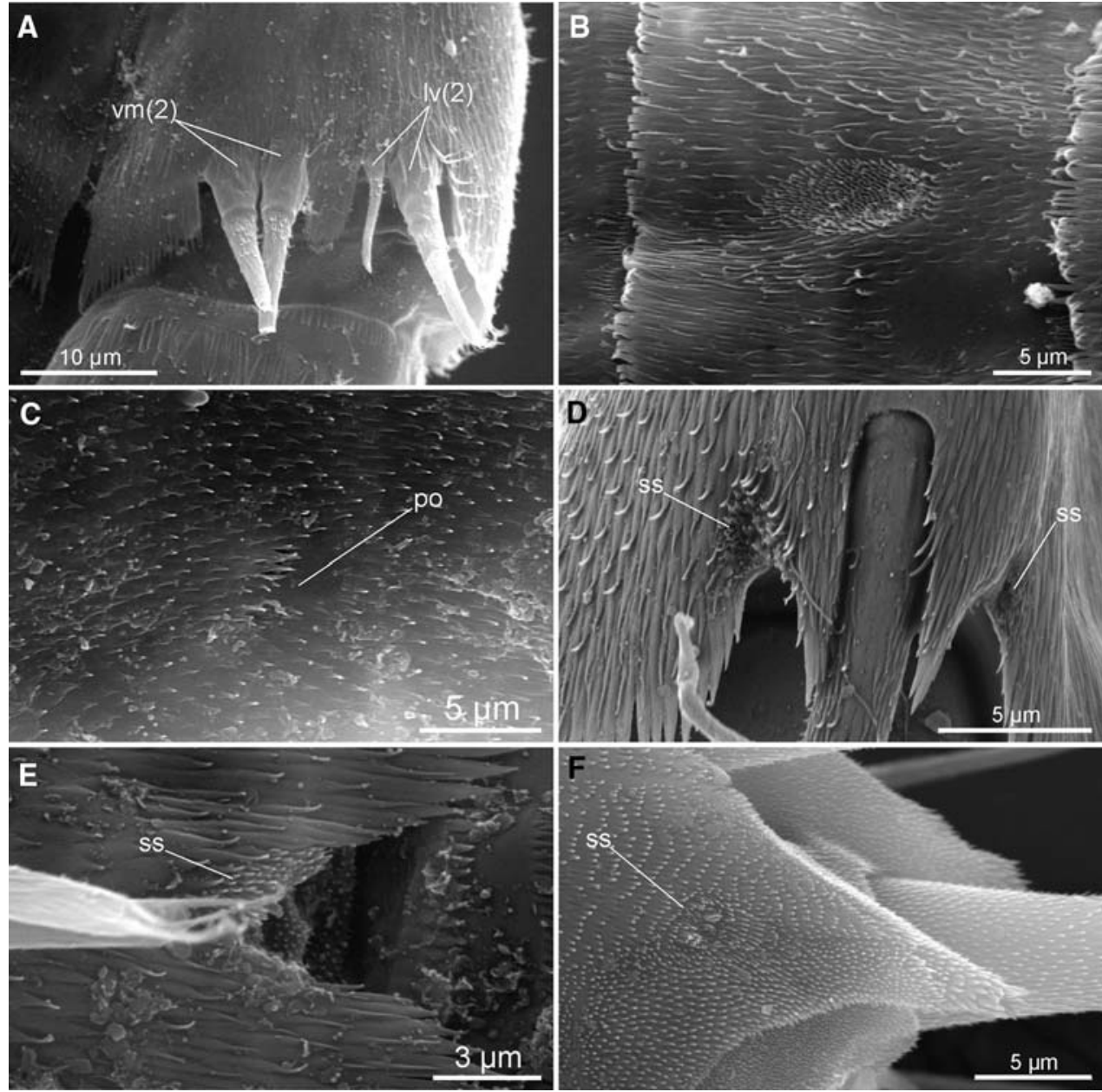

Segment 6 has a middorsal spine, flanked by a pair of paradorsal sensory spots and basal notches. A pair of elongate sensory spots composed of numerous minute papillae and one pore is located in a sublateral position (Fig. 1b). One acicular spine is present in the lateroventral notch (Figs. 1b, 2c, 5c). The secondary fringe, middorsal spine (Fig. 6d), cuticular hairs and notches on the posterior margin of the ventral side are otherwise as on the previous segment.

Segment 7 possesses a middorsal spine, flanked by a pair of paradorsal sensory spots and basal notches. Pairs of lateroventral tubules and acicular spines are located in the lateroventral notch (Figs. 1b, 2e, 5d). The acicular spine is closest to the midventral line. The secondary fringe, middorsal spine, cuticular hairs and notches on the posterior margin of the ventral side are otherwise as on the previous segment.

Segment 8 shows a middorsal spine, flanked by a pair of paradorsal sensory spots and basal notches. One pair of long lateroventral acicular spines is located in the lateroventral notch (Figs. 1b, 2e, 5d). Tubules are absent. The secondary fringe, middorsal spine, cuticular hairs and notches on the posterior margin of the ventral side are otherwise as on the previous segment.

Segment 9 has a middorsal spine, flanked by a pair of paradorsal sensory spots and basal notches. One pair of long lateroventral acicular spines is located in the lateroventral notch (Figs. 1b, 2e, 5d). The ventromedial and ventrolateral notches are located closer to each other and are only separated by a small, pointed flap. A very inconspicuous laterodorsal pore may indicate the location of the protonephridial opening (Fig. 6c). The secondary fringe, middorsal spine, cuticular hairs and notches on the posterior margin of the ventral side are otherwise as on the previous segment.

Segment 10 possesses a middorsal spine, flanked by a pair of paradorsal sensory spots and basal notches. Lateroventral acicular spines are not present. Females have an unpaired acicular middorsal spine, which is considerably shorter than the middorsal spines on the previous segments, and one pair of subdorsal acicular spines (Figs. 1d, 5e). The middorsal and paired subdorsal spines are present in males also but these are more flexible, and appear segmented or moniliform in their distal ends (Figs. 1a, 2g, 5f). The 
Table 1 Measurements of adult Tubulideres seminoli nov. gen et sp., including number of measured specimens $(n)$ and SD

\begin{tabular}{lllll}
\hline Character & $n$ & Range & Mean & SD \\
\hline TL & 10 & $331-424 \mu \mathrm{m}$ & $366 \mu \mathrm{m}$ & $24.70 \mu \mathrm{m}$ \\
SW & 6 & $53-80 \mu \mathrm{m}$ & $64 \mu \mathrm{m}$ & $10.60 \mu \mathrm{m}$ \\
SW/TL & 6 & $14.7-22.4 \%$ & $17.5 \%$ & $3.22 \%$ \\
MSW-6 & 6 & $49-74 \mu \mathrm{m}$ & $62.5 \mu \mathrm{m}$ & $9.67 \mu \mathrm{m}$ \\
MSW/TL & 6 & $13.6-19.3 \%$ & $17.0 \%$ & $2.20 \%$ \\
LTS/TL & 10 & $22.4-33.4 \%$ & $28.1 \%$ & $2.94 \%$ \\
LTAS/TL & 10 & $23.8-34.6 \%$ & $30.9 \%$ & $3.10 \%$ \\
LTAS/LTS & 10 & $84.5-147.0 \%$ & $110 . \%$ & $16.93 \%$ \\
MTS/TL & 7 & $81.4-117.8 \%$ & $100 . \%$ & $13.06 \%$ \\
S1 & 9 & $31-42 \mu \mathrm{m}$ & $36 \mu \mathrm{m}$ & $3.60 \mu \mathrm{m}$ \\
S2 & 10 & $30-41 \mu \mathrm{m}$ & $36 \mu \mathrm{m}$ & $3.43 \mu \mathrm{m}$ \\
S3 & 10 & $32-44 \mu \mathrm{m}$ & $36 \mu \mathrm{m}$ & $4.05 \mu \mathrm{m}$ \\
S4 & 10 & $34-44 \mu \mathrm{m}$ & $37 \mu \mathrm{m}$ & $3.40 \mu \mathrm{m}$ \\
S5 & 10 & $31-42 \mu \mathrm{m}$ & $38 \mu \mathrm{m}$ & $3.62 \mu \mathrm{m}$ \\
S6 & 10 & $36-45 \mu \mathrm{m}$ & $40 \mu \mathrm{m}$ & $2.30 \mu \mathrm{m}$ \\
S7 & 10 & $37-53 \mu \mathrm{m}$ & $44 \mu \mathrm{m}$ & $4.22 \mu \mathrm{m}$ \\
S8 & 10 & $40-49 \mu \mathrm{m}$ & $45 \mu \mathrm{m}$ & $2.88 \mu \mathrm{m}$ \\
S9 & 10 & $43-52 \mu \mathrm{m}$ & $47 \mu \mathrm{m}$ & $2.70 \mu \mathrm{m}$ \\
S10 & 10 & $37-50 \mu \mathrm{m}$ & $41 \mu \mathrm{m}$ & $4.08 \mu \mathrm{m}$ \\
S11 & 10 & $26-38 \mu \mathrm{m}$ & $32 \mu \mathrm{m}$ & $4.32 \mu \mathrm{m}$ \\
\hline
\end{tabular}

LTAS Lateral terminal accessory spine; LTS lateral terminal spine; $M S W$ maximum sternal width; MTS midterminal spine; $S W$ standard width; $S 1-11$ segment lengths of trunk segments $1-11 ; T L$ trunk length

middorsal and subdorsal spines in both genders are located in deep notches near the posterior margin of the segment. A small, rounded sensory spot is located in a laterodorsal position. A slightly larger ventromedial sensory spot is present as well (Fig. 1b, e), but it is not associated with a ventromedial notch as on the previous segments. Ventromedial and lateroventral notches on the posterior margin of the segment are not present. Female gonopores are present on the border between segment 10 and 11 (Figs. 2h, 5g). The secondary fringe and cuticular hairs appear as those on the previous segment.

Segment 11 shows a long middorsal spine, paired lateral terminal spines, lateral terminal accessory spines and an unpaired midterminal spine (Figs. 1, 2a, g-h, 5d-g). The midterminal spine is very long, flexible and flagellar in its distal end (Figs. 1c, 2a). On the dorsal side the segment terminates into two, paired cone-shaped extensions with distal sensory spots (type 3 sensory spots), located dorsal to the midterminal spine (Fig. 5e). A pair of small sensory spots is present in a somewhat paradorsal position near the bases of the cone-shaped extensions (Figs. 1a, 6f). Paired concentrations of papillae lateral to the middorsal spine indicate the presence of a second pair of paradorsal modified sensory spots (type 3). Modified sensory spots (type 3 ) are furthermore
Table 2 Spine/tubule measurements of adult Tubulideres seminoli nov. gen et sp. including number of measured specimens $(n)$ and SD

\begin{tabular}{|c|c|c|c|c|}
\hline Character & $n$ & Range $(\mu \mathrm{m})$ & Mean $(\mu \mathrm{m})$ & $\mathrm{SD}(\mu \mathrm{m})$ \\
\hline MD 1 & 10 & $32-40$ & 36 & 2.45 \\
\hline MD 2 & 10 & $36-61$ & 47 & 7.52 \\
\hline MD 3 & 10 & $47-70$ & 56 & 6.67 \\
\hline MD 4 & 10 & $54-74$ & 65 & 6.48 \\
\hline MD 5 & 10 & $58-74$ & 66 & 5.27 \\
\hline MD 6 & 9 & $59-75$ & 67 & 5.96 \\
\hline MD 7 & 9 & $55-69$ & 61 & 5.14 \\
\hline MD 8 & 9 & $50-75$ & 65 & 8.59 \\
\hline MD 9 & 9 & $53-73$ & 62 & 7.28 \\
\hline MD 10 (f) & 4 & $51-62$ & 58 & 5.00 \\
\hline MD $10(\mathrm{~m})$ & 3 & $35-38$ & 36 & 1.53 \\
\hline SD 10 (f) & 5 & $43-46$ & 44 & 1.30 \\
\hline SD $10(m)$ & 5 & $37-41$ & 39 & 1.64 \\
\hline MD 13 & 6 & $161-186$ & 177 & 9.40 \\
\hline LV 2 (o) & 8 & $12-16$ & 15 & 1.39 \\
\hline LV 2 (i) & 10 & $19-23$ & 21 & 1.45 \\
\hline VM 2 & 10 & $14-20$ & 17 & 2.04 \\
\hline LV 4 & 10 & $19-24$ & 21 & 1.85 \\
\hline LV 5 (o) & 10 & $16-23$ & 21 & 1.85 \\
\hline LV 5 (i) & 10 & $22-28$ & 24 & 1.76 \\
\hline LV 6 & 10 & $35-44$ & 39 & 3.30 \\
\hline LV 7 (o) & 10 & $22-28$ & 25 & 1.93 \\
\hline LV 7 (i) & 10 & $41-48$ & 44 & 2.18 \\
\hline LV 8 & 9 & $55-65$ & 61 & 3.03 \\
\hline LV 9 & 9 & $55-69$ & 63 & 4.25 \\
\hline LTS & 10 & 83-119 & 103 & 11.00 \\
\hline LTAS & 10 & $101-124$ & 112 & 8.60 \\
\hline MTS & 7 & $309-393$ & 364 & 30.87 \\
\hline
\end{tabular}

When differences in size occur, closely set tubules/spines are marked with $\mathrm{i}=$ inner and $\mathrm{o}=$ outer, where "inner" means closest to the midventral line and "outer" means closest to the lateral side. The notations $(\mathrm{f})=$ female and $(\mathrm{m})=$ male refer to the specific gender when sexual dimorphism occurs

LTAS Lateral terminal accessory spine; LTS lateral terminal spine; $L V$ lateroventral; $M D$ middorsal; $M T S$ midterminal spine; $S D$ subdorsal; $V M$ ventromedial

located laterally at the bases of the lateral terminal spines (Fig. 5h). A secondary fringe with conspicuously long fringes exists in the anterior part of the tergal plate.

Phylogenetic remarks Tubulideres gen. nov. is characterized by having trunk segments consisting of a closed ring in the first segment, an arched tergal plate with a midventral articulation and wedge-shaped posterior extension in the second segment, and following segments consisting of a tergal and two sternal plates. Cuspidate spines are absent, but several segments have flexible tubules, and especially the second segment is equipped with a concentration of three pairs of minute tubules and one pair of even shorter, 
Table 3 Summary of nature and location of sensory spots, pores, spines, and tubules arranged by series in Tubulideres seminoli nov. gen. et sp

\begin{tabular}{|c|c|c|c|c|c|c|c|c|}
\hline Segment & MD & PD & SD & LD & SL & LA & LV & VM \\
\hline 1 & $\mathrm{ac}$ & ss & & & & & & ss \\
\hline 2 & $\mathrm{ac}$ & ss & & ss & & & $\mathrm{ac}, \mathrm{tu}$ & tu, tu \\
\hline 3 & $\mathrm{ac}$ & ss & & & & & & ss \\
\hline 4 & $\mathrm{ac}$ & ss & & & & & ac & ss \\
\hline 5 & $\mathrm{ac}$ & ss & & & & & $\mathrm{ac}, \mathrm{tu}$ & ss \\
\hline 6 & ac & ss & & & ss & & $\mathrm{ac}$ & ss \\
\hline 7 & $\mathrm{ac}$ & ss & & & & & tu, ac & ss \\
\hline 8 & $\mathrm{ac}$ & ss & & & & & $\mathrm{ac}$ & ss \\
\hline 9 & ac & ss & & po & & & ac & ss \\
\hline 10 & ac & & $\mathrm{ac}$ & ss & & & & ss, ss \\
\hline 11 & $\mathrm{ac}, \mathrm{mt}$ & $\mathrm{ss}, \mathrm{ss}, \mathrm{ss}$ & & & & ltas & lts, ss & \\
\hline
\end{tabular}

$L A$ Lateral accessory; $L D$ laterodorsal; $L V$ lateroventral; $M D$ middorsal; $P D$ paradorsal; $S D$ subdorsal; $S L$ sublateral; $V M$ ventromedial. $a c$ acicular spine; ltas lateral terminal accessory spine; lts lateral terminal spine; $m t$ midterminal spine; ss sensory spot; $t u$ tubule

flexible spines. This trait is unique among kinorhynchs. The middorsal spines are alternatingly offset to a position lateral to the middorsal line, and the number of sensory spots is relative low. The combination of these characters and in particular the tubule concentration on the second segment justify the erection of a new genus.

Tubulideres gen. nov. clearly belongs to the Cyclorhagae, based on the presence of a broad midventral placid and the first trunk segment consisting of a closed ring. However, it is difficult to assign the genus to any existing family. Alternatingly relocated middorsal spines are found in Dracoderidae only (Higgins and Shirayama 1990; Adrianov and Malakhov 1999), but since Tubulideres seminoli gen. et sp. nov. apparently does not share any other synapomorphies with species of this rather different genus, we consider this similarity as being a convergence.

The presence of a midterminal spine and middorsal spines suggests a position close to the Centroderidae. The Centroderidae is currently also the only group characterized by having the first trunk segment consisting of a closed ring, midventral articulation on the second segment and (at least) the following segments consisting of a tergal and two sternal plates. However, centroderids have a second segment consisting of a tergal and two sternal plates (Higgins 1969; Martorelli and Higgins 2004; Neuhaus 2004), whereas the second segment in Tubulideres seminoli gen. et sp. nov. consists of a tergal plate with a midventral articulation only. The cuticle in centroderids furthermore appears much thicker than in Tubulideres seminoli gen. et sp. nov. (see Figs. 5.11-5.13 in Adrianov and Malakhov 1999 and discussion below), and all centroderids lack the conspicuous lateroventral notches in the posterior margin of the tergal plate that otherwise characterize Tubulideres seminoli gen. et sp. nov. (Fig. 5c, d). Hence, a close relationship with species of the Centroderidae is not likely.

The trunk segments in Antygomonas incomitata and A. oreas are reported to consist of a closed ring in the first segment and a single plate with a midventral articulation in the following ten segments (Nebelsick 1990; Bauer-Nebelsick 1996). Reinvestigation of the type material revealed, however, that extremely indistinct articulations can be observed ventrolaterally on segments 3-11 (see also Nebelsick 1990, Fig. 13) which suggests that those segments consist of a tergal and two sternal plates as in Tubulideres seminoli gen. et sp. nov. As in Tubulideres seminoli gen. et sp. nov. the lateral articulation lines in species of Antygomonas are very easily overlooked, hence it is not surprising that they were missed in the original descriptions. However, unpublished observations on additional species of Antygomonas from the Central American East Pacific doubt the existence of these lateral articulations (B. Neuhaus, personal observation) and studies of sectioned specimens are probably required to confirm whether or not sternal plates are present.

Furthermore, Tubulideres seminoli gen. et sp. nov. and species of Antygomonas have a very similar architecture related to the middorsal spines, i.e., middorsal spines on the posterior margin of the segment, flanked by paired notches and paradorsal sensory spots (Fig. 6d), and lateroventral notches in the tergal plate (Fig. 5c, d; Nebelsick 1990; Bauer-Nebelsick 1996). These similarities may be interpreted as potential synapomorphic characters of species of Tubulideres gen. nov. and Antygomonas. However, "middorsal spines on all segments" also occur in species of Sphenoderes, Semnoderes, Centroderes and Campyloderes (Zelinka 1928; Higgins 1967, 1969; Nebelsick 1990; Neuhaus 2004; Bauer-Nebelsick 1996). Lateroventral notches also exist in species of Cateria (Gerlach 1956; Higgins 1968). Therefore, these characters may belong to the ground pattern of Kinorhyncha and could be evaluated as symplesiomorphic characters.

Tubulideres seminoli gen. et sp. nov. also differs from species of Antygomonas at several points. For example, are main placids in Tubulideres seminoli gen. et sp. nov. fused with segment 1 , and it lacks interstitial placids, cuspidate spines and the prominent dorsal and ventral indentations in the anterior margin of first trunk segment, whereas species of Antygomonas (see Nebelsick 1990; Bauer-Nebelsick 1996) do not possess the peculiar tubules on the posterior margin of segment 2 (Figs. 1b, 2c, 5c). These differences stress that Tubulideres seminoli gen. et sp. nov. and species of Antygomonas cannot be considered congeneric. On the other hand, one might be tempted to assign Tubulideres seminoli gen. et sp. nov. to the family Antygomonidae, based on the presence of notches in the posterior segment 
margins and the general similarities of the body cuticle in species of Antygomonas and Tubulideres seminoli gen. et sp. nov. However, as discussed above, we hesitate in doing so as these and other similarities all could be considered as symplesiomorphies. Hence, at present we prefer not to assign Tubulideres seminoli gen. et sp. nov. to any specific family, but to consider it as a species incertae sedis for the class Cyclorhagida.

Morphological remarks The distribution of scalids in the introvert of Tubulideres seminoli gen. et sp. nov. follows a 5, 5, 10, 9 pattern for the mouth cone and a 10,10, $10,15,15,15,14$ pattern of the introvert. A similar pattern is present in various other species such as Antygomonas oreas (see Bauer-Nebelsick 1996) and the homalorhagid species Kinorhynchus phyllotropis, Paracentrophyes praedictus, and probably Pycnophyes communis (see Brown 1989; Neuhaus 1995). Also Echinoderes capitatus has a very similar pattern, with the only exception that the midventral trichoscalid is replaced by the normal scalid of ring 06, meaning that ring 06 possesses 14 scalids only (Nebelsick 1993). It should, however, be stressed that the scalid patterns apparently vary greatly, even on generic levels [see Neuhaus (1995) for a summary], hence nothing can be concluded at the present state.

The articulation of the outer oral styles with only two segments and a claw-like structure differs from the oral styles of $A$. oreas that are reported to have three segments and no pore (Bauer-Nebelsick 1996). Since the pore might be confused with a second articulation, especially when observed in light microscopy, it is not unlikely that the oral styles in A. oreas and A. incomitata consist of only two segments and a pore as well. However, it would require reinvestigations with SEM to confirm this hypothesis.

As discussed in previous papers (see, e.g., Sørensen 2006), consideration of new characters and character complexes is important in order to obtain substantial information for analyses of the phylogenetic relationships within Kinorhyncha. An interesting character concerns the thickness of the cuticle. Cuticle thickness has previously been discussed in relation to kinorhynch phylogeny and evolution (Adrianov and Malakhov 1995; Neuhaus 1995). A thick and well-developed cuticle is typically present in species of the cyclorhagid families Echinoderidae and Centroderidae and in the homaloragid Pycnophyidae, whereas a thinner and more flexible cuticle is found in species of Cateria, Zelinkaderes, Antygomonas, Semnoderidae and the homalorhagid Neocentrophyidae (Higgins 1968, 1969; Kristensen and Higgins 1991; Nebelsick 1990; Adrianov and Malakhov 1995, 1999; Bauer-Nebelsick 1995, 1996; Neuhaus 1995; Ga Ordónez et al. 2000). The cuticle in Tubulideres seminoli gen. et sp. nov. certainly belongs to the thin and flexible type, with rather indistinct articulations between the segmental plates (Figs. $2 \mathrm{a}-\mathrm{e}, 5 \mathrm{a}-\mathrm{d}$ ). It has been suggested that the thin cuticle displays the ancestral kinorhynch state, whereas the thicker type evolved independently within the cyclorhagid and homalorhagid lineages (Adrianov and Malakhov 1995; Neuhaus 1995). This would place Tubulideres seminoli gen. et sp. nov., and probably its close allied species of Antygomonas, among the most basal kinorhynchs. However, the exact position cannot be determined yet as the notches in the posterior margin of most trunk segments resemble the pattern in species of Cateria (see Higgins 1968), whereas the general appearance of the cuticle points towards a position closer to Antygomonas.

Order Cyclorhagida Zelinka, 1896

Suborder Cyclorhagae Zelinka, 1896

Family Zelinkaderidae Higgins, 1990

Zelinkaderes brightae sp. nov.

(Figs. 7, 8, 9, 10, 11, 12; Tables 4, 5, 6),

Diagnosis Trunk segments 1 through 11 with serially arranged patches with cuticular bristles displaying a longitudinally striated pattern. Middorsal spines present on segments 4, 6, 8-11; lateroventral short acicular spines present on segment 2; lateral accessory cuspidate spines present on segments 2 and 8; ventrolateral cuspidate spines present on segments 4-6 and 9; lateroventral acicular spines present on segments 8,9 and 11 (=lateral terminal spine); midterminal and lateral terminal accessory spines present on segment 11. Females with acicular middorsal and subdorsal spines on segment 10; males with spines in same positions, but spines are more flexible, appearing segmented or moniliform in their distal ends. Lateral terminal accessory spines shorter than lateral terminal spines, ratio $=72.1-87.5 \%$.

Etymology The species is named after Dr. Monika Bright in recognition of her excellent work on Zelinkaderes and Antygomonas - the latter being another intriguing kinorhynch genus.

Material examined All type material was obtained from a sample taken on 22 July 2003 in the Atlantic Ocean, ca. 6 miles off Fort Pierce, Florida. Position: $27^{\circ} 29.559^{\prime} \mathrm{N}$, $080^{\circ} 12.233^{\prime} \mathrm{W}$. Holotype: adult male, mounted in Fluoromount $G^{\circledR}$ (ZMUC KIN-184). Allotype: adult female, mounted in Fluoromount $\mathrm{G}^{\circledR}$ (ZMUC KIN-185). Paratypes: 2 adult females, 2 adult males and one juvenile, mounted in Fluoromount $\mathrm{G}^{\circledR}$ (ZMUC KIN-186 to KIN-190). All types are stored at the Zoological Museum, University of Copenhagen.

Description The adult specimens possess a head, a neck and eleven trunk segments (Fig. 7a, b, 8a, 11a, b). All measurements and dimensions are given in Tables 4, 5. A summary of spine and sensory spot locations is given in Table 6.

The head consists of a narrow mouth cone and an introvert with seven rings of scalids (Figs. 8f, 9, 10). Helioscalids 
Fig. 7 Zelinkaderes brightae sp. nov. a Female dorsal view. b Female ventral view. c Male, left part of trunk segments 10-11 dorsal view. d. Male, left part of trunk segments 10-11 ventral view

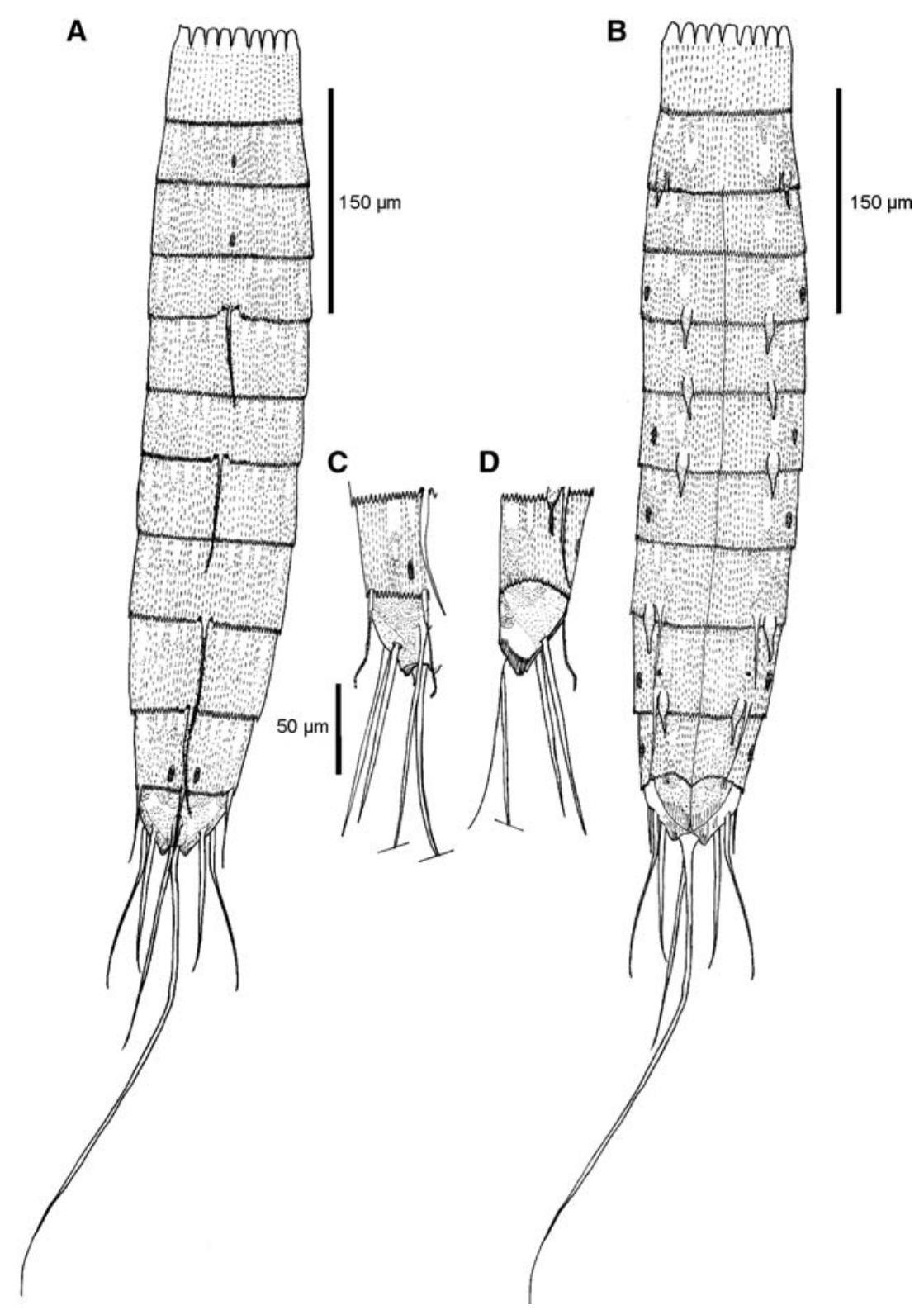

and the first ring of inner oral styles (rings -03 and -02 ) are feebly visible in the examined specimens, but the second ring (ring -01) of inner oral styles appears to consist of ten styles that resemble the larger outer oral styles. The following ring (ring 00) consists of nine outer oral styles with two segments and conspicuously pointed tips (Figs. 8f, 10a). The spinoscalids (ring 01) are equipped with dense fringes on their bases (Figs. 9, 10c). Distally to the fringes, a pair of spines extends from the basal plate of each spinoscalid (Fig. 10c). Ring 02 and 03 have no recognizable scalids. However, ring 02 carries ten pairs of spines, similar to those of the spinoscalids. It furthermore has rows of fringes, aligned to the radius arms and hence located directly under the spines. Ring 03 has twenty single spines followed by rows of fringes like in ring 02. Rings 04, 05 and 06 consist of fifteen regular sized scalids, with rows of fringes between the rings (Figs. 9, 10c, d). The scalids of ring 05 are furthermore accompanied by eyelid-like structures (Fig. 10d) that might correspond to basal plates. Ring 07 has 14 rather small trichoscalids with one in a midventral position. In summary, the distribution of scalids per ring can currently be reported as: ?, ?, 10, 9/10, *, *, 15, 15, 15, 14. Described section-wise (Fig. 9) the scalid arrangement in the introvert is as follows: All sections (except the middorsal section 6) with 1 oral style; section 1 furthermore with four scalids and one trichoscalid; sections 2, 4, 6, 8, 10: five scalids and one trichoscalid; and sections 3, 5, 7, 9: four scalids and two trichoscalids.

The neck consists of 16 soft and indistinct placids of uniform size (Fig. 10b). The placids have two longitudinal folds, mostly visible in SEM, but are otherwise smooth. The basal parts of the lateral placid margins are visible as 
Fig. 8 Light microscope photos of Zelinkaderes brightae gen. et sp. nov. Holotypic male: a dorsal view. b Trunk segments 1-6 dorsal view. $\mathbf{c}$ Trunk segments 1-6 ventral view. d Terminal trunk segment 8-11 dorsal view. e Trunk segments 8-11 ventral view. f Introvert and trunk segments 1-2 dorsal view. g Terminal trunk segment in male dorsal view. Allotypic female: $\mathbf{h}$ terminal trunk segment in female dorsal view. $h p$ hairless patch; $l d$ laterodorsal spines in male $(\mathrm{m})$ and female (f); os outer oral style
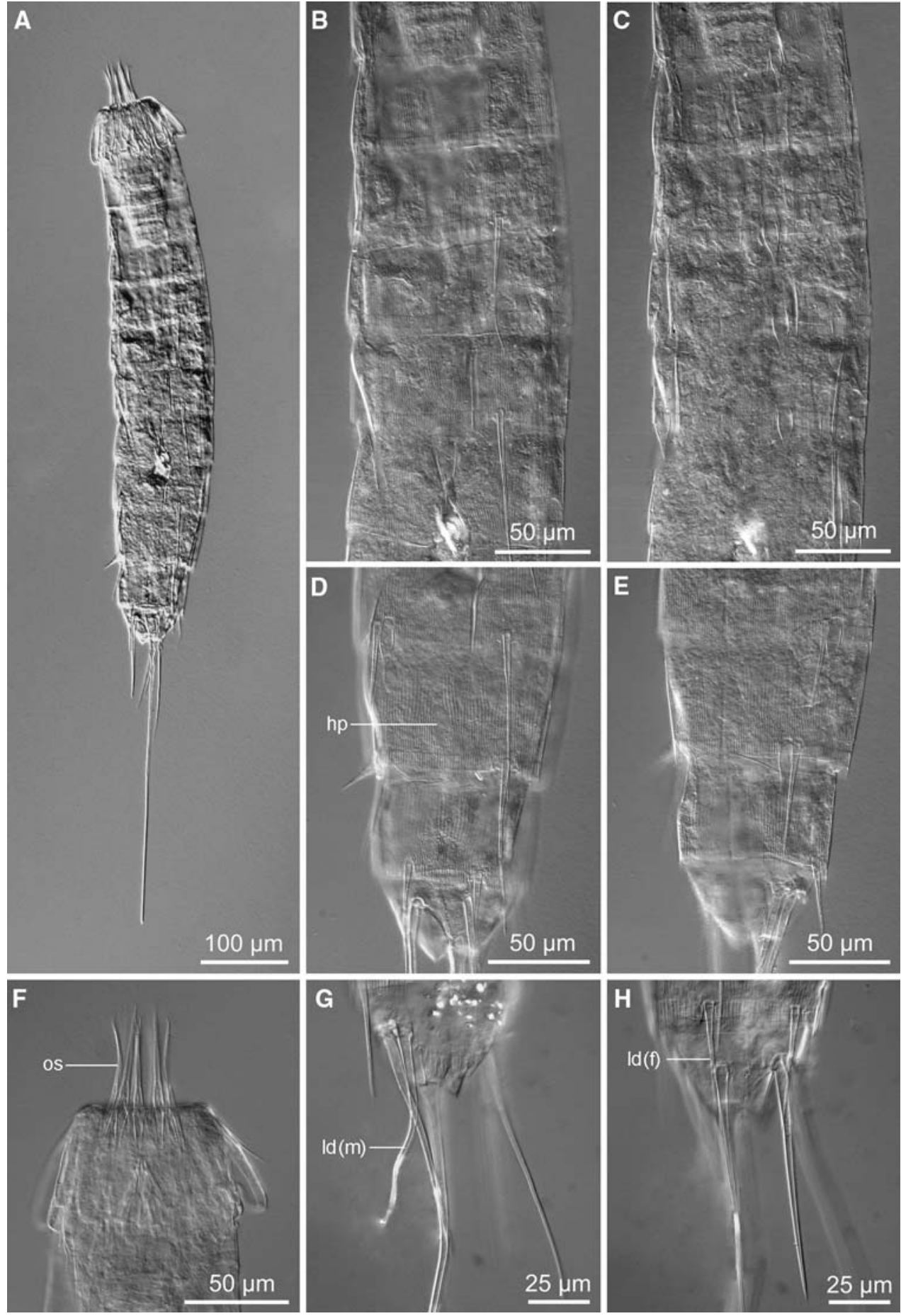

indistinct lines on the anterior part of trunk segment 1. All placids are fused with segment 1 and the segment border is indistinct in LM. However, the border is easily seen in SEM because of the conspicuous striated surface sculpturing of segment 1 differs from the smooth surface on the placids (Figs. 10b, 11d).

Segment 1 consists of one complete cuticular ring (Figs. 7a, b, 11a-b). This and the following segments are covered with small scale-like, longitudinally arranged bristles that give the animal a conspicuous striated appearance (Figs. 7a, b, 8b-e, 11c-h). The lateral edges of the bristles are slightly swollen, which may give the erroneous impression that each longitudinal line is formed by a double row of fine hairs. Other kinds of cuticular hairs are absent. Posteriorly, the segment terminates into a pectinate fringe.

Segment 2 has one pair of very short and flexible lateroventral acicular spines and a pair of lateral accessory cuspidate spines (Figs. 7b, 11d, 12b). The acicular spines are 


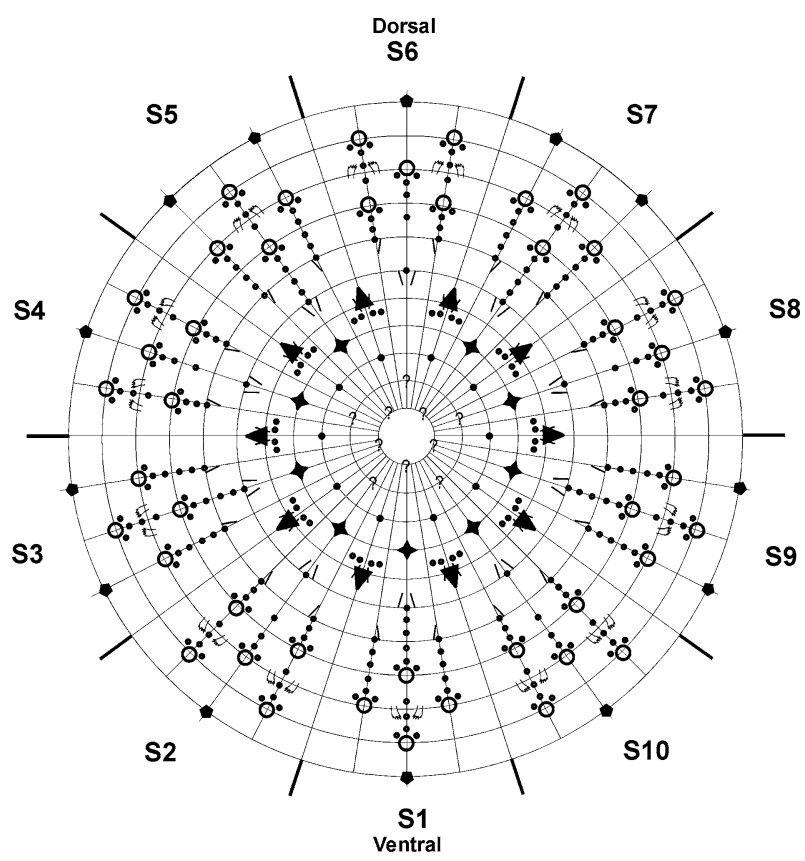

Zelinkaderes brightae nov. spec.

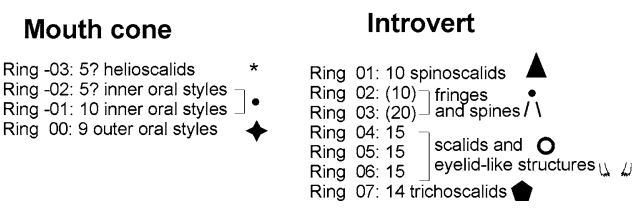

Fig. 9 Diagram of mouth cone and introvert showing distribution of oral styles and scalids in Zelinkaderes brightae sp. nov

extremely small and inconspicuous (Fig. 12b), whereas the cuspidate spines are considerably larger, and the broad base constitutes more than $50 \%$ of the spine. An oval mid- dorsal sensory spot is located slightly posterior to the mid of the segment. The surface sculpturing is similar to the sculpturing on segment 1 . However, it has several patches without cuticular bristles or with bristles displaying a different pattern and appearance (Fig. 7). All these patches are elongate and extend posteriorly from the anterior margin of the segment. In the ventromedial position the segment has one pair of large, less hirsute patches (corresponding patches on segments 9 and 10 are documented on Fig. 11f). Laterally it has two smaller patches totally devoid of cuticular hairs or bristles. These patches are also elongate and extend posteriorly from the anterior margin of the segment, but the patches are otherwise much smaller than the laterodorsal ones. In the laterodorsal position it has a pair of patches that are lanceolate in shape, starting at the anterior margin of the segment and extending posteriorly through three-fourth of the segment length. The integument surface in the anterior part of the patches is smooth and without any kind of hair or bristle structures. On the posterior part, the periphery is covered with small cuticular bristles, whereas the center is hairless (corresponding patches on segments 9 and 10 are documented on Fig. 11e). Three further pairs of hairless patches are located more dorsally (corresponding paradorsal patch on segment 10 is documented on Fig. 12f).

Segment 3 and the following 7 segments consist of a tergal plate with midventrally fused sides (Fig. 7b). The segment has no spines. An oval middorsal sensory spot is located slightly posterior to the mid of the segment. The surface sculpturing displays the same striation as present on the previous segments, and several patches with differing surface sculpturing are present. A pair of large patches
Fig. 10 Scanning electron micrographs of details in the introvert of Zelinkaderes brightae sp. nov. a Head with introvert and oral styles extended dorsal view. b Placids and closed head aperture. $\mathbf{c}$ Detail of spinoscalid attachment sites in section 4 of the introvert. d Detail in the middorsal section 6 of scalid rings in introvert. el eyelid-like structure; $f r$ fringes in introvert; $m v p$ midventral placid; $o s$ outer oral style; $s$ spines in introvert; $s c$ scalids; $s p$ spinoscalid in introvert ring 01. Digits refer to the specific introvert ring of each structure
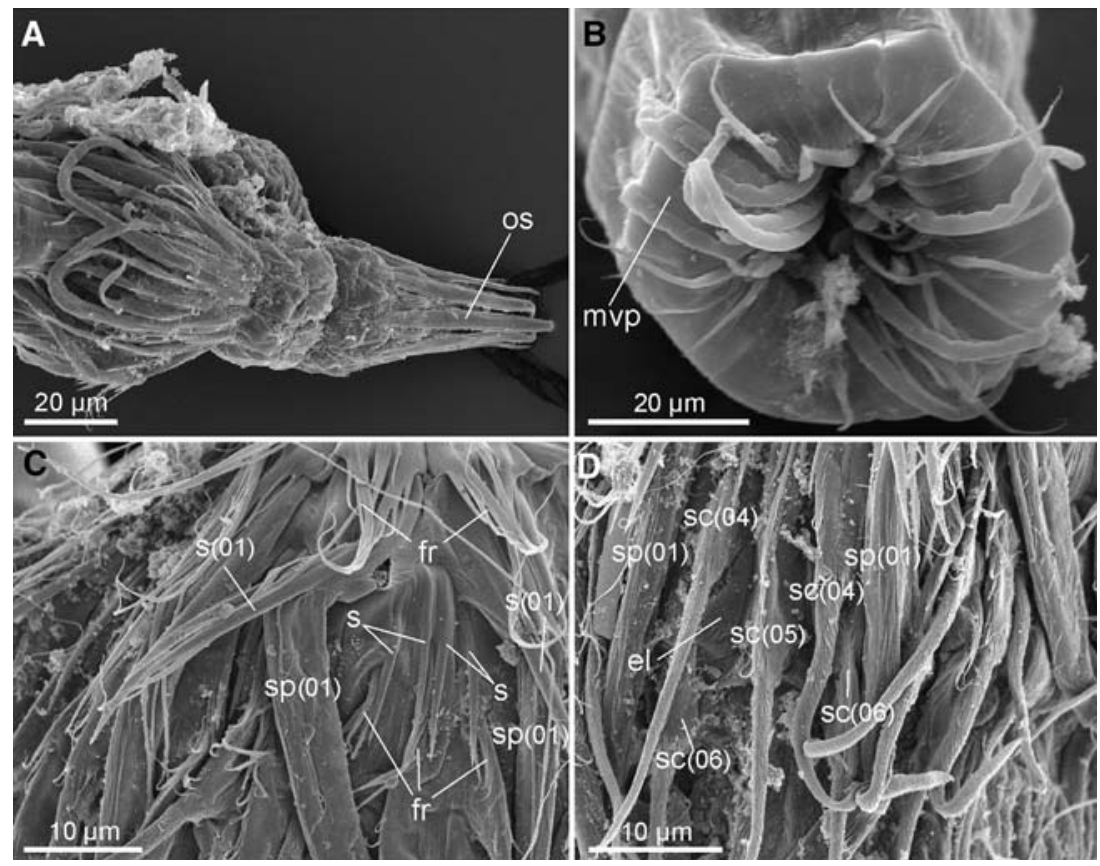
covered with cuticular bristles is located very close to the midventral line. These patches are equivalent with the ventromedial patches on the previous segment. The laterodorsal patches with bristles are repeated from segment 2 , and the smaller hairless patches are present as two pairs in a ventrolateral position, two pairs in a lateral position and three pairs in the subdorsal position.

Segment 4 has one middorsal spine located near the posterior segment margin, and one pair of ventrolateral cuspidate spines (Figs. 7a, b, 8b-c, 11c). The middorsal spine is composed of a less hirsute shaft and a distal part with densely set cuticular hairs (corresponding middorsal spine on segment 10 is documented on Fig. 12a). One pair of small paradorsal sensory spots is located at the base of the spine. The ventrolateral cuspidate spines are similar to those on segment 2. One pair of elongate midlateral sensory spots is located mesially on the segment (Fig. 12e). The patches without hairs or bristles are repeated from segment 3.

Segment 5 has no middorsal spine but one pair of ventrolateral cuspidate spines (Figs. 7b, 11c). The cuspidate spines (Fig. 12c) are similar to those on segment 4. Midlateral sensory spots are absent. The patches without hairs or bristles are repeated from segment 4 .

Segment 6 has one middorsal spine located near the posterior margin, and one pair of ventrolateral cuspidate spines (Figs. 7a, b, 8b, c, 11c). The cuspidate spines are similar to those on segment 5 . One pair of small paradorsal sensory spots is located at the base of the middorsal spine, whereas another larger, elongate pair is located in a midlateral position mesially on the segment. The patches without hairs or bristles are repeated from segment 5 .

Segment 7 has no spines (Figs. 7a, b, 8b, c, 11c). One pair of elongate midlateral sensory spots is located mesially on the segment. The patches without hairs or bristles are repeated from segment 6 .

Segment 8 has one middorsal spine located near the posterior margin, one pair of closely set lateral accessory cuspidate spines and one pair of lateroventral acicular spines (Figs. 7a, b, 8d-e, 11e). A pair of small paradorsal sensory spots is located at the base of the middorsal spine. Otherwise, the segment has no sensory spots. The patches without hairs or bristles are repeated from segment 7 .

Segment 9 has one middorsal spine located near the posterior margin, one pair of ventrolateral cuspidate spines and one pair of lateroventral acicular spines (Figs. 7a, b, 8d, e, $11 \mathrm{e}, \mathrm{f})$. One pair of small paradorsal sensory spots is located at the base of the middorsal spine. Furthermore, one pair of elongate midlateral sensory spots (Fig. 11e) and one pair of much smaller, rounded ventromedial sensory spots are located slightly behind the mesial part of the segment. The patches without hairs or bristles are repeated from segment 8 .
Segment 10 has one middorsal spine located near the posterior margin and one pair of laterodorsal acicular spines (Figs. 7a, b, 8d, e, 11e, g-h). Ventral and more lateral spines are absent. In females the middorsal and laterodorsal spines are regular acicular (Figs. 8h, 11g), whereas those in the males appear more flexible and segmented or moniliform in their distal ends (Figs. 7c, d, 8g, 11h). One pair of small paradorsal sensory spots is located at the base of the middorsal spine, two pairs of much larger oval sensory spots are located in a paradorsal (Fig. 12f) and midlateral position, respectively. The posterior margins of the sternal plates are broadly concave, not straight like on the previous segments. The patches without hairs or bristles are repeated from segment 9 .

Segment 11 tapers strongly to the base of the midterminal spine. The segment consists of one tergal and two sternal plates. One middorsal spine, without associated paradorsal sensory spots, is located on the mid of the tergal plate. Furthermore, a midterminal spine, paired lateral terminal spines and lateral terminal accessory spines are present (Figs. 7, 8a, g, h, 11a, g, h). A pair of paradorsal sensory spots with two pores is located mesially on the segment, anterior to a pair of modified sensory spots (type 3 sensory spots), located at the base of the midterminal spine (Fig. 12d). The surface sculpturing differs from the previous segments. The most anterior part of the tergal plate has three paired patches with very densely set short cuticular hairs (Fig. 12d). The posterior margins of the patches are very distinct, whereas the anterior margins are covered by the pectinate fringe of segment 10 . The most dorsal pair of patches each contains one conspicuous circular area without hairs. Another two pairs of patches are located between the middorsal spine and the lateral accessory terminal spines. The rest of the plate is covered with short, extremely delicate hairs. The sternal plates are broad at their anterior ends, and taper gradually towards a medial tip at the fringed posterior margins of each plate. The surface sculpturing consists of two medial patches on the anterior part of each plate. The patches have distinct posterior margins and are covered with densely set short cuticular hairs posteriorly. The anterior parts are less hirsute. Close to the midventral line of the segment two large patches extend from the anterior segment margin till the mid of the segment. Each patch is rounded posteriorly and covered with densely set short cuticular hairs, except in the center that lacks hairs completely. Lateral to the patches the cuticle is covered with less densely set hairs. In females the gonopores are visible as two strongly cuticularized areas at the intersegmental junction between segments 10 and 11 . The posterior halves of the sternal plates lack hairs completely.

Phylogenetic remarks Based on the presence of trunk segments 1 and 2 consisting of closed cuticular rings, 16 placids that are fused with segment 1 , and scale-like cuticular 
Fig. 11 Scanning electron micrographs of Zelinkaderes brightae sp. nov. a Female lateral view. b Female dorsolateral view. c Trunk segments 3-6 lateral view. d Trunk segments $1-3$ lateral view. e Trunk segments 9-10 lateral view. f Trunk segments 9-10 ventral view. g Female trunk segments 9-11 lateral view. h Male, trunk segments 10-11lateral view. $h p$ Hairless patch; $l a$ lateral accessory cuspidate spine; $l d$ laterodorsal spines in male $(\mathrm{m})$ and female (f); ltas lateral terminal accessory spine; $l v$ lateroventral acicular spine; $m d$ middorsal spines in male (m) and female (f); $m t s$ midterminal spine; $s s$ sensory spot; $v l$ ventrolateral cuspidate spine. Digits after spines/tubules refer to segment number
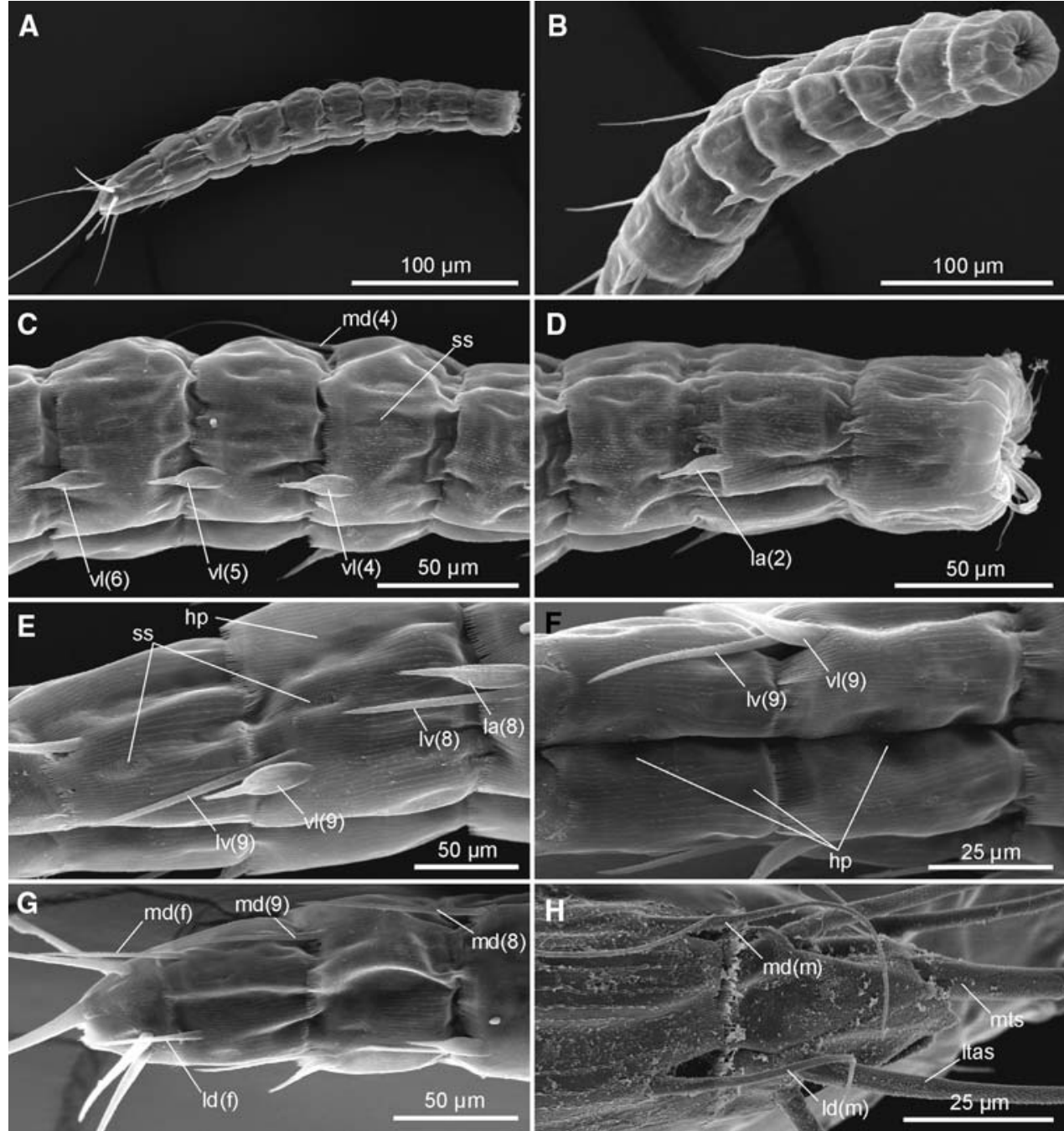

hairs arranged in a conspicuous longitudinal striated pattern, the new species is easily assigned to the genus Zelinkaderes. Until now, Zelinkaderes has contained three species only: Zelinkaderes floridensis Higgins (1990), Z. submersus (Gerlach 1969) and Z. klepali Bauer-Nebelsick (1995) (see Gerlach 1969; Higgins 1990; Bauer-Nebelsick 1995).

The morphology within Zelinkaderes appears to be rather constant (except for introverts; see below) and the four species can be distinguished by differences in the formulas of the lateral and ventral spine series. Most spines are found in $Z$. submersus, which has somewhat lateral spines on trunk segments 2 and 4-9 (Higgins 1990). Zelinkaderes brightae nov. sp. displays a similar pattern, but lateral spines are lacking on segment 7 (Fig. 7b), whereas Z. klepali in addition lacks lateral spines on segments 4, 6 and 7 (Bauer-Nebelsick 1995). Zelinkaderes floridensis has lateral spines on segments 5, 8 and 9 only (Higgins 1990).

It seems reasonable to propose that speciation in Zelinkaderes happened through a series of spine reductions or additions, depending on the character polarity, which would place $Z$. brightae nov. sp. in a position between $Z$. submersus and Z. klepali. As we at present do not understand the basal kinorhynch relationships, it is not possible to determine whether absence or presence of lateral spines on most segments represents the ancestral state for species of the genus. Based on comparison with species of other cyclorhagid genera with relatively soft cuticle, e.g. Antygomonas, Tubulideres gen. nov. and species of Semnoderidae (Zelinka 1928; Higgins 1967, 1969; Nebelsick 1990; Bauer-Nebelsick 1996; see also "Phylogenetic remarks" under Tubulideres gen. nov.), it would be reasonable to expect the "spines on most segments" as being the plesiomorphic state and consecutive reduction of spines as being the apomorphic condition. In such a case, Z. brightae nov. sp. would represent the sister species to Z. klepali + Z. floridensis.

The morphology of the introvert confirms the proposed close relationship with Z. klepali. Bauer-Nebelsick (1995) reported the scalid distribution in Z. klepali to follow a 5, 5, 
Fig. 12 Scanning electron micrographs of details in Zelinkaderes brightae sp. nov. a Trunk segment 8 , middorsal spine. b Trunk segment 2, lateral accessory cuspidate spine and lateroventral acicular spine. c Trunk segment 5, lateroventral cuspidate spine. d Trunk segment 11 lateral view. e. Trunk segment 4, midlateral sensory spot. f Trunk segment 10, large paradorsal sensory spot and hairless patch. $h p$ hairless patch; $l a$ lateral accessory cuspidate spine; $l v$ lateroventral acicular spine; mss modified sensory spot; ss sensory spot
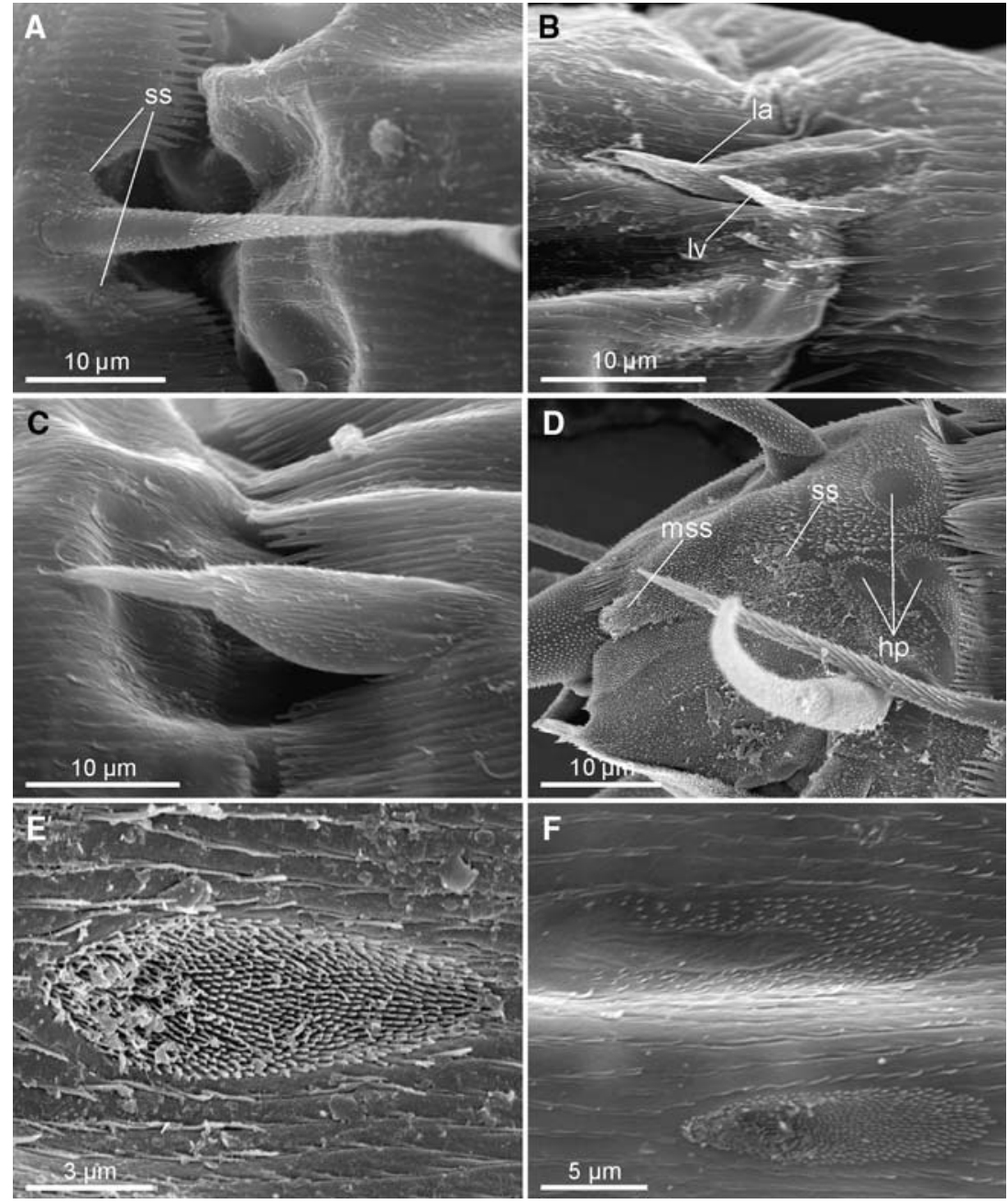

$10,9 / 10, *, *, 15,15,15,14$ pattern, which is identical with the pattern in Z. brightae (Fig. 9), but stands in a sharp contrast to Z. floridensis which displays a 5, 5, 10, 9/10, 5, 10, 15,*,*, 14 pattern (Higgins 1990).

Comparison of introvert morphology within Zelinkaderes and with species of other genera is hampered by the apparent reduction of certain scalid rings (ring 02 and 03 in Z. brightae nov. sp. and Z. klepali, and ring 05 and 06 in Z. floridensis). To establish the ground pattern for scalid distribution in Zelinkaderes it would be useful to know the number of scalids that originally was present in the reduced rings. Here, we might be able to get a clue from the presence of spines and fringes in Z. brightae nov. sp. (Figs. 9, $10 \mathrm{c}, \mathrm{d})$ that could be interpreted as markers after reduction of scalids. This would suggest that the original oral style/ scalid pattern prior to the reduction was ?, ?, 10, $9 / 10$, (10), (20), 15, 15, 15, 14. Interestingly, this pattern is very similar to the pattern in species of Antygomonas and Tubulideres seminoli gen. et sp. nov. (except for ring 03 that consists of 10 scalids only; Nebelsick 1990; Bauer-Nebelsick 1996; this paper), which could indicate a relationship between these taxa. However, data is scarce among species of other kinorhynchs (see, e.g., Neuhaus 1995).

\section{Morphological and taxonomic remarks}

The complex scalid pattern in the introvert of $Z$. brightae nov. sp., prompted the introduction of two new terms for components in the introvert. The term "spines" was used to characterise stiff extensions of the basal plates (Fig. 10c). They can be distinguished from the scalids by the lack of any articulation and their attachment to the basal plates. They are glabrous and have a pointed tip. The component referred to as "eyelid-like structure" is used for the structures in ring 05 that look like eyelids or wings (Fig. 10d). The structures resemble a halved scalid basal plate.

The general morphology of Z. brightae nov. sp. corresponds very well with the original diagnosis of Zelinkaderes that was given by Higgins (1990). However, even more traits appear to be characteristic for species of this 
Table 4 Measurements of adult Zelinkaderes brightae nov. sp., including number of measured specimens $(n)$ and SD

\begin{tabular}{lllll}
\hline Character & $n$ & Range & Mean & SD \\
\hline TL & 5 & $505-650 \mu \mathrm{m}$ & $564 \mu \mathrm{m}$ & $55.69 \mu \mathrm{m}$ \\
LTS/TL & 5 & $18.2-21.2 \%$ & $20.1 \%$ & $1.3 \%$ \\
LTAS/TL & 5 & $15.1-18.6 \%$ & $16.3 \%$ & $1.42 \%$ \\
LTAS/LTS & 5 & $72.1-87.5 \%$ & $81.1 \%$ & $5.86 \%$ \\
MTS & 2 & $425-497 \mu \mathrm{m}$ & $461 \mu \mathrm{m}$ & $50.91 \mu \mathrm{m}$ \\
MTS/TL & 2 & $65.4-86.0 \%$ & $75.7 \%$ & $14.57 \%$ \\
S1 & 5 & $52-66 \mu \mathrm{m}$ & $59 \mu \mathrm{m}$ & $6.16 \mu \mathrm{m}$ \\
S2 & 5 & $43-53 \mu \mathrm{m}$ & $47 \mu \mathrm{m}$ & $4.38 \mu \mathrm{m}$ \\
S3 & 5 & $46-51 \mu \mathrm{m}$ & $48 \mu \mathrm{m}$ & $2.07 \mu \mathrm{m}$ \\
S4 & 5 & $48-60 \mu \mathrm{m}$ & $52 \mu \mathrm{m}$ & $4.97 \mu \mathrm{m}$ \\
S5 & 5 & $49-60 \mu \mathrm{m}$ & $53 \mu \mathrm{m}$ & $4.30 \mu \mathrm{m}$ \\
S6 & 5 & $53-63 \mu \mathrm{m}$ & $58 \mu \mathrm{m}$ & $4.00 \mu \mathrm{m}$ \\
S7 & 5 & $55-72 \mu \mathrm{m}$ & $62 \mu \mathrm{m}$ & $6.47 \mu \mathrm{m}$ \\
S8 & 5 & $57-75 \mu \mathrm{m}$ & $66 \mu \mathrm{m}$ & $7.33 \mu \mathrm{m}$ \\
S9 & 5 & $63-83 \mu \mathrm{m}$ & $69 \mu \mathrm{m}$ & $8.41 \mu \mathrm{m}$ \\
S10 & 5 & $57-72 \mu \mathrm{m}$ & $63 \mu \mathrm{m}$ & $5.59 \mu \mathrm{m}$ \\
S11 & 5 & $42-55 \mu \mathrm{m}$ & $48 \mu \mathrm{m}$ & $5.10 \mu \mathrm{m}$ \\
\hline
\end{tabular}

LTAS Lateral terminal accessory spine; LTS lateral terminal spine; MTS midterminal spine; S1-11 segment lengths of trunk segments 111; $T L$ trunk length

genus. These include the presence of ventrolateral cuspidate spines on trunk segment 5, lateral accessory cuspidate spines and lateroventral acicular spines on segment 8 , and lateroventral acicular spines and ventrolateral cuspidate spines on segment 9.

The lateroventral spines on segment 10 have been moved to a more laterodorsal position, compared to the spines on the previous segments. This displacement also appears to be consistent for all four Zelinkaderes species. In Z. floridensis and Z. submersus, Higgins (1990) refers to their position as subdorsal, but according to the new and more precise spine terminology for spines locations, proposed by Pardos et al. (1998), their position is rather laterodorsal as in Z. brightae nov. sp. and Z. klepali.

Also the cuticular sculpturing is highly characteristic for species of the genus. The presence of cuticular bristles arranged in longitudinal rows gives the cuticle a conspicuous striated appearance. This striation was described from both $Z$. floridensis and Z. submersus, but the descriptions were solely based on light microscopy, hence Higgins (1990) interpreted the striation as an internal pattern. Bauer-Nebelsick (1995) confirmed this assumption by TEM studies of Z. klepali (Bauer-Nebelsick 1995: Figs. 40-42) and also confirmed the presence of longitudinally arranged rows of bifid cuticular bristles. Similar bristles are also found in $Z$. brightae nov. sp.
Table 5 Spine/tubule measurements of adult Zelinkaderes brightae nov. sp. including number of measured specimens $(n)$ and SD

\begin{tabular}{lllll}
\hline Character & $n$ & Range $(\mu \mathrm{m})$ & Mean $(\mu \mathrm{m})$ & SD $(\mu \mathrm{m})$ \\
\hline MD 4 & 5 & $64-88$ & 73 & 9.04 \\
MD 6 & 5 & $76-101$ & 87 & 10.67 \\
MD 8 & 5 & $62-84$ & 74 & 8.62 \\
MD 9 & 5 & $65-87$ & 76 & 9.59 \\
MD 10 (f) & 2 & $55-60$ & 58 & 3.54 \\
MD 10 (m) & 3 & $47-60$ & 55 & 7.23 \\
LD 10 (f) & 2 & $46-50$ & 48 & 2.83 \\
LD 10 (m) & 3 & $53-63$ & 55 & 6.81 \\
MD 13 & 5 & $109-175$ & 139 & 24.26 \\
LA 2 & 5 & $20-26$ & 23 & 2.59 \\
LV 2 & 4 & $10-16$ & 13 & 2.50 \\
VL 4 & 5 & $24-27$ & 26 & 1.14 \\
VL 5 & 5 & $25-28$ & 27 & 1.30 \\
VL 6 & 5 & $26-32$ & 29 & 2.50 \\
LA 8 & 5 & $28-33$ & 31 & 2.28 \\
LV 8 & 5 & $41-68$ & 50 & 10.67 \\
LV 9 & 5 & $47-92$ & 50 & 17.10 \\
VL 9 & 5 & $29-33$ & 31 & 1.48 \\
LTS & 5 & $105-136$ & 113 & 13.17 \\
LTAS & 5 & $84-96$ & 91 & 6.46 \\
MTS & 5 & $425-497$ & 461 & 50.91 \\
\hline The not & & 513 & \\
\hline
\end{tabular}

The notations $(\mathrm{f})=$ female and $(\mathrm{m})=$ male refer to the specific sex when sexual dimorphism occurs

LA Lateral accessory; LTAS lateral terminal accessory spine; LTS lateral terminal spine; $L V$ lateroventral; $M D$ middorsal; $M T S$ midterminal spine; $V L$ ventrolateral

Table 6 Summary of nature and location of sensory spots, spines, and tubules arranged by series in Zelinkaderes brightae $\mathrm{n}$. $\mathrm{sp}$

\begin{tabular}{|c|c|c|c|c|c|c|c|c|}
\hline Segment & MD & PD & LD & ML & LA & LV & VL & VM \\
\hline \multicolumn{9}{|l|}{1} \\
\hline 2 & ss & & & & $\mathrm{cu}$ & ac & & \\
\hline 3 & ss & & & & & & & \\
\hline 4 & ac & ss & & ss & & & $\mathrm{cu}$ & \\
\hline 5 & & & & & & & $\mathrm{cu}$ & \\
\hline 6 & $\mathrm{ac}$ & ss & & ss & & & $\mathrm{cu}$ & \\
\hline 7 & & & & ss & & & & \\
\hline 8 & $\mathrm{ac}$ & ss & & & $\mathrm{cu}$ & ac & & \\
\hline 9 & $\mathrm{ac}$ & ss & & ss & & $\mathrm{ac}$ & $\mathrm{cu}$ & ss \\
\hline 10 & ac & ss, ss & ac & ss & & & & \\
\hline 11 & $\mathrm{ac}, \mathrm{mt}$ & ss, ss & & & ltas & lts & & \\
\hline
\end{tabular}

$L A$ Lateral accessory; $L D$ laterodorsal; $L V$ lateroventral; $M D$ middorsal; $M L$ midlateral; $P D$ paradorsal; $S D$ subdorsal; $V L$ ventrolateral; $V M$ ventromedial. $a c$ acicular spine; $c u$ cuspidate spine; ltas lateral terminal accessory spine; lts lateral terminal spine; $m t$ midterminal spine; $s s$ sensory spot 


\section{Genus Zelinkaderes}

Emended diagnosis Oral styles consisting of two segments. Neck consisting of 16 indistinct placids, all fused with first trunk segment; midventral placid broader than remaining ones. Segments 1 and 2 consisting of one closed cuticular ring. Segments 3 to 11 with lateral margins of single tergal plate articulating midventrally. Middorsal spines present on segments 4, 6, 8-11. Lateroventral cuspidate spines present on segment 5. Midlateral cuspidate spines and sublateral acicular spines present on segment 8 . Lateral accessory acicular spines and lateroventral cuspidate spines present on segment 9. Laterodorsal acicular spines (moniliform in males) present on segment 10. Midterminal spines present in juveniles and adults. Lateral terminal and lateral terminal accessory spines present in both sexes in adults. Segments 1 through 11 with conspicuous longitudinal striation formed by rows of cuticular bristles.

Acknowledgments We are indebted to Valerie Paul and the staff at the Smithsonian Marine Station at Fort Pierce for providing us with excellent research facilities during our stays at the station, and to the crew on R/V Sunburst, Hugh Reichardt and Woody Lee. We also thank Dr. Reinhardt M. Kristensen, Jesper G. Hansen and Thomas M. Jespersen for their help collecting the samples. We thank Dr. Helmut Sattmann at the Museum of Natural History in Vienna and Dr. Monika Bright for providing type and supplementary material of Antygomonas oreas and Cheryl Bright at the National Museum of Natural History, Smithsonian Institution, for providing type specimens of Zelinkaderes floridensis and Z. submersus. This is contribution no. 693 from the Smithsonian Marine Station at Fort Pierce. Funding was provided by the Danish Natural Science Research Council (Grants No. 21-04-0331 and 21-04-0047). The compound microscope, camera lucida and imaging software were funded by the Carlsberg Foundation (Grant No. 2005-1-545) and the Novo Nordisk Foundation.

\section{References}

Adrianov AV (1989) First record of kinorhynchs from the Sea of Japan. Zool Zhurn 68:17-27. [In Russian]

Adrianov AV, Malakhov VV (1995) The phylogeny and classification of the class Kinorhyncha. Zoosyst Ross 4:23-44

Adrianov AV, Malakhov VV (1999) Cephalorhyncha of the world ocean. KMK LTD, Moscow

Adrianov AV, Murakami C, Shirayama Y (2002a) Echinoderes aureus n. sp. (Kinorhyncha: Cyclorhagida) from Tanabe Bay (Honshu Island), Japan, with a key to the genus Echinoderes. Spec Div 7:47-66

Adrianov AV, Murakami C, Shirayama Y (2002b) Taxonomic study of the Kinorhyncha in Japan. III. Echinoderes sensibilis n. sp (Kinorhyncha: Cyclorhagida) from Tanabe Bay. Zool Sci 19:463-473

Bauer-Nebelsick M (1995) Zelinkaderes klepali sp.n., from shallow water sands of the Red Sea. Ann Nat Hist Mus Wien 97B:57-74

Bauer-Nebelsick M (1996) Antygomonas oreas sp.n., a new deep-sea kinorhynch from the Pacific Ocean. Ann Nat Hist Mus Wien 98B:5-22

Brown R (1989) Morphology and ultrastructure of the sensory appendages of a kinorhynch introvert. Zool Scr 18:471-482
Gardónez D, Pardos B, Benito J (2000) Cuticular structures and epidermal glands of Echinoderes cantabricus and E. hispanicus (Kinorhyncha, Cyclorhagida) with special reference to their taxonomic value. J Morphol 246:161-178

Gerlach SA (1956) Über einen aberranten Vertreter der Kinorhynchen aus dem Küstengrundwasser. Kieler Meeresforsch 12:120-124

Gerlach SA (1969) Cateria submersa sp.n., ein cryptorhager Kinorhynch aus dem sublitoralen Mesopsammal der Nordsee. Ver Inst Meeresforsch, Bremerhaven 12:161-168

Higgins RP (1967) The Kinorhyncha of New-Caledonia. Expédition Francaise sur les Recifs coralliens de la Nouvelle-Calédonie. Paris Fondation Singer-Polignac 2:75-90

Higgins RP (1968) Taxonomy and postembryonic development of the Cryptorhagae, a new suborder for the mesopsammic kinorhynch genus Cateria. Trans Am Microsc Soc 87:21-39

Higgins RP (1969) Indian Ocean Kinorhyncha:1, Condyloderes and Sphenoderes, new cyclorhagid genera. Smithsonian Contr Zool 14:1-13

Higgins RP (1990) Zelinkaderidae, a new family of cyclorhagid Kinorhyncha. Smithsonian Contr Zool 500:1-26

Higgins RP, Shirayama Y (1990) Dracoderidae, a new family of the cyclorhagid Kinorhyncha from the Island Sea of Japan. Zool Sci Jpn 7:1-13

Kristensen RM, Higgins RP (1991) Kinorhyncha. In: Harrison FW, Ruppert EE (eds) Microscopic anatomy of invertebrates, vol 4. Wiley-Liss, New York, pp 377-404

Lemburg C (2002) A new kinorhynch Pycnophyes australensis sp. n. (Kinorhyncha: Homalorhagida: Pycnophyidae) from Magnetic Island, Australia. Zool Anz 241:173-189

Martorelli S, Higgins RP (2004) Kinorhyncha from the stomach of the shrimp Pleoticus muelleri (Bate, 1888) from Comodoro Rivadavia, Argentina. Zool Anz 243:85-98

Nebelsick M (1990) Antygomonas incomitata gen. et sp. n. (Cyclorhagida, Kinorhyncha) and its phylogenetic relationships. Zool Scr 19:143-152

Nebelsick M (1993) Introvert, mouth cone, and nervous system of Echinoderes capitatus (Kinorhyncha, Cyclorhagida) and implications for the phylogenetic relationships of Kinorhyncha. Zoomorphology 113:211-232

Neuhaus B (1995) Postembryonic development of Paracentrophyes praedictus (Homalorhagida): neoteny questionable among the Kinorhyncha. Zool Scr 24:179-192

Neuhaus B (2004) Description of Campyloderes cf. vanhoeffeni (Kinorhyncha, Cyclorhagida) from the Central American East Pacific deep sea with a review of the genus. Meiofauna Marina 13:3-20

Neuhaus B, Blasche T (2006) Fissuroderes, a new genus of Kinorhyncha (Cyclorhagida) from the deep sea and continental shelf of New Zealand and from the continental shelf of Costa Rica. Zool Anz 245:19-52

Neuhaus B, Higgins RP (2002) Ultrastructure, biology, and phylogenetic relationships of Kinorhyncha. Integr Comp Biol 42:619-632

Pardos F, Higgins RP, Benito J (1998) Two new Echinoderes (Kinorhyncha, Cyclorhagida) from Spain, including a reevaluation of kinorhynch taxonomic characters. Zool Anz 237:195-208

Sørensen MV (2006) New kinorhynchs from Panama, with a discussion of some phylogenetically significant cuticular structures. Meiofauna Marina 15:51-77

Sørensen MV, Jørgensen A, Boesgaard TM (2000) A new Echinoderes (Kinorhyncha: Cyclorhagida) from a submarine cave in New South Wales, Australia. Cah Biol Mar 41:167-179

Sørensen MV, Heiner I, Ziemer O (2005) A new species of Echinoderes from Florida (Kinorhyncha: Cyclorhagida). Proc Biol Soc Wash 118:499-508

Zelinka K (1928) Monographie der Echinodera. Verlag von Wilhelm Engelmann in Leipzig, Leipzig 